\title{
Upskilling: Do Employers Demand Greater Skill When Skilled Workers Are Plentiful?
}

\section{Alicia Sasser Modestino, Daniel Shoag, and Joshua Ballance}

\begin{abstract}
:
Using a large database of online job postings, we demonstrate that employee skill requirements rise when there is a larger supply of relevant job seekers. We identify this effect using variation across time, occupations, and places, which allows us to control for potentially confounding factors. We further exploit the natural experiment arising from troop withdrawals from Iraq and Afghanistan over this period as a shock to local, occupation-specific labor supply. Our estimates imply that the increase in national unemployment rates from 2007 to 2010 increased requirements for a bachelor's degree within occupations by 2.2 percentage points and increased the fraction requiring two or more years of experience by 3.5 percentage points.
\end{abstract}

JEL Classifications: J23, J24, J63

Keywords: upskilling, middle skills, vacancies, labor demand, employer search

Alicia Sasser Modestino is an associate professor of public policy and urban affairs and economics in the college of social sciences and humanities of Northeastern University. Her e-mail address is a.modestino@neu.edu. When the research for this paper was conducted she was a senior economist with the New England Public Policy Center in the research department of the Federal Reserve Bank of Boston. Daniel Shoag is a visiting scholar with the New England Public Policy Center and an assistant professor of public policy with the Taubman Center for State and Local Government at the John F. Kennedy School of Government of Harvard University His email address is Dan Shoag@hks.harvard.edu. Joshua Balance is a senior research assistant with the New England Public Policy Center. His email address is joshua.ballance@bos.frb.org.

This paper, which may be revised, is available on the web site of the Federal Reserve Bank of Boston at http://www.bostonfed.org/economic/wp/index.htm.

This paper presents preliminary analysis and results intended to stimulate discussion and critical comment. The views expressed herein are those of the authors and do not indicate concurrence by the Federal Reserve Bank of Boston or by the principals of the Board of Governors or the Federal Reserve System.

The authors thank David Autor, Bill Dickens, Chris Foote, Yolanda Kodrzycki, Jessica Wolpaw Reyes, Jonathan Rothwell, Robert Triest, Jeff Zabel, Bo Zhao, Burning Glass Technologies, and seminar participants from the Federal Reserve Bank of Boston, the Federal Reserve System Committee on Microeconomic Analysis, the Harvard Kennedy School, and Northeastern University for their valuable comments and insights. We also thank the Russell Sage Foundation for their generous support of this work (award \#85-14-05). All remaining errors are our own.

This version: January 30, 2015 


\section{Motivation: Shifting Requirements for Skill}

The Great Recession and subsequent recovery have been particularly painful for lowskilled workers. From 2007 to 2012, the unemployment rate rose by 6.4 percentage points for noncollege workers while it rose by only 2.3 percentage points for the college educated. Perhaps less well known, this differential impact was evident within occupations as well. According to the American Community Survey, college-educated workers were 2 percentage points less likely to be unemployed during 2007 through 2010, even after controlling for differences across occupational codes.

One explanation for the differential impact may be the ability of high-skilled workers to take middle- and low-skilled jobs. Indeed, from 2007 to 2012 the share of workers with a college degree in traditionally middle-skill occupations increased rapidly, as shown in Figure 1. Carnevale, Jayasundera, and Cheah (2012) similarly documents that in the current economic recovery a greater share of newly hired workers in traditionally low-, middle-, and high-skill occupations were college educated than was the case before the recession. Such growth in skill requirements within occupations has colloquially become known as "upskilling."1

It is not clear from employment outcomes alone, however, whether the increasing share of high-skilled workers in middle- and low-skill occupations reflects changing search behavior on the part of workers, changing behavior by employers, or some combination of the two.. To the best of our knowledge, the literature has not yet determined whether the education and experience requirements for job postings have risen over this period, and if so, whether this rise was driven by the state of the local labor market. In this paper, we tackle this question using a novel dataset of online job vacancy postings. ${ }^{2}$

\footnotetext{
${ }^{1}$ A large literature explores changing employment outcomes across occupations during the Great Recession. See Autor (2013), Beaudry, Green, and Sand (2013), Charles, Hurst, and Notowidigdo (2013), and Jaimovich and Siu (2014) for examples.

${ }^{2}$ In this paper, we focus on the relationship between changes in labor supply and changing requirements in job openings. Firms may also alter their mix of high- and low-skilled employees by selectively firing workers, rather than by hiring new workers. However, data from the Current Population Survey show that the share of unemployed workers with a bachelor's degree was positively correlated with the change in the state unemployment rate between 2007 and 2012, suggesting that employers were not simply selectively firing workers with lower education levels.
} 
The data, which come from commercial vacancy aggregators like Burning Glass Technologies (BGT) and Help Wanted Online (HWOL), contain information on 11.6 million online vacancies collected from over 15,000 sources. Each vacancy is coded for 70 different characteristics, including location, occupation, and experience and education requirements. The data are preprocessed by the vendor to remove duplicates and "evergreen" postings that are not removed even though the underlying vacancy has been closed. Similar data have been widely used in recent research (see Sahin et al. 2014, Davis, Faberman, and Haltiwanger 2012, and Marinescu and Rathelot 2012 for examples). The great advantage of these data is that they permit us to measure requirements over time for state-by-detailed-occupation cells.

With this variation, we are able to isolate the relationship between weak local labor markets and rising skill requirements. Using different measures of labor supply and a wide array of controls, including both state and occupation fixed effects, we find that employers increase both education and experience requirements when job searchers are plentiful. Our baseline estimates indicate that a 1 percentage point increase in the local unemployment rate raises the fraction of jobs requiring a bachelor's degree by 0.5 percentage point and the fraction of jobs requiring two or more years of experience by 0.8 percentage point. These increases are relative to baseline fractions of 24.1 percent and 22.8 percent of jobs requiring these skills in 2012. Using an instrumental variables approach for housing market downturns (Mian and Sufi 2014), we show that these effects are not plausibly driven by reverse causality. We further show that these results are comparable across traded and nontraded industries, and therefore not driven by local demand shocks.

Finally, to cleanly identify this relationship, we exploit a natural experiment associated with troop withdrawals from Iraq and Afghanistan over this period. Roughly 150,000-250,000 veterans per year re-entered the domestic labor force from 2009 to 2012. The timing of these drawdowns was driven by strategic and political considerations and was independent of local economic conditions. Nevertheless, certain states and occupations received significantly larger labor supply shocks than others. We show that these particular state-occupation combinations correspondingly experienced a significant increase in their skill requirements: logisticians (an occupation with many veterans) experienced significant upskilling, whereas occupational 
therapy assistants, an occupation with few veterans, did not. These relationships survive controls for state and occupation fixed effects and imply effects on the same order of magnitude as the baseline results.

The finding that weaker labor markets lead to rising job posting requirements is important for both labor economics and macroeconomics. A long literature has looked at polarization in skill requirements across occupations in recent U.S. history (Katz and Murphy 1992, Autor, Katz, and Kearney 2008, Autor and Dorn 2013) and European history (Goos and Manning 2007), and a more recent literature has explored the rising polarization across industries and occupations during recessions (Tüzemen and Willis 2013, Jaimovich and Siu 2014, and Foote and Ryan 2012). We focus on the related, but distinct topic of within-occupation skill demand. Using vacancy postings we can isolate the response of labor demand (rather than just the equilibrium outcome), and we are able to document an important and novel feedback mechanism between labor supply and the selectivity of vacancies. This mechanism may be relevant for macroeconomic models with heterogeneous workers (Mortensen and Pissarides 1994, Gautier 2002, and Albrecht and Vrooman 2002) and welfare analysis (Merkl and van Rens 2012). It also builds on a small, but growing literature on employer job requirements (Gautier et al. 2002 and Marinescu and Wolthoff 2012).

Our results indicate that the demand for skilled workers is perhaps more dynamic and responsive to labor market conditions than previously thought. Indeed, since 2007, several states, including Maryland, Washington, and Michigan, have redesigned their worker training and education programs using real-time labor market information contained in online job postings to make them more responsive to the perceived demand for skilled labor. Such information can be used to help the unemployed search more efficiently, to guide individual choices when selecting a program of study, and to design training and education programs at community colleges and other institutions that are responsive to employer demands. ${ }^{3}$

This paper also documents the extent to which rising skill requirements are driven by the cyclicality of the labor market, shedding light on the persistence of the demand for increased skills that has been observed within occupations. The question of persistence is particularly

\footnotetext{
${ }^{3}$ http://www.mass.edu/vpconference/documents/Skills2Compete_ForgottenJobs_MA_EMBARGOED.pdf
} 
relevant for younger workers just entering the labor market who are likely to be less skilled and experienced. Increasingly stringent employer requirements for education and experience raise the bar for these young workers at a time when firms have slashed their budgets for formal training programs. Our findings suggest that during a downturn state policymakers should consider expanding internships and apprenticeships that can give younger workers the experience necessary to gain entry into a middle-skill job.

The paper proceeds as follows. Section II describes the dataset used in our estimation. Section III presents the basic relationships between skill requirements and unemployment rates, and Section IV discusses robustness tests for alternate interpretations. Section V reports the results of our analysis, exploiting troop drawdowns to identify labor supply shocks. Section VI concludes.

\section{Data: Measuring Trends in Employer Skill Requirements}

Anecdotal reports have suggested rising demand for skills within occupations since 2007 due to the larger number of available applicants per opening. For example, in a survey of 2,200 employers conducted by CareerBuilder at the end of 2013, 58 percent of respondents said they were able to hire college degree holders for traditionally high-school level work "because of the (state of the)... labor market." Yet at the same time, 55 percent of respondents said the reason for hiring more B.A. recipients was because "skills for my positions have evolved, requiring higher-educated labor." ${ }^{4}$ Despite these observations, few researchers have been able to quantify rising employer requirements, due to the difficulty in isolating labor demand from labor supply. In this paper, we are able to study changes in hiring dynamics by using a large, detailed dataset of online job postings.

\footnotetext{
${ }^{4}$ CareerBuilder is an online vacancy data source that purports to cover upwards of 90 percent of the online job market. This data source also allows for real-time analysis on labor supply and demand for arbitrarily small geographies by occupation and/or industry that are similar to Burning Glass Technologies. In addition to scraping third-party data from online job boards and employer sites, CareerBuilder also includes vacancies from their own fee-based online posting service. See CareerBuilder. 2014. "Education Requirements for Employment on the Rise, According to CareerBuilder Survey."

http://www.careerbuilder.com/share/aboutus/pressreleasesdetail.aspx?sd=3\%2F20\%2F2014\&id=pr813\&ed=12\%2F31 $\% 2 \mathrm{~F} 2014$
} 
Online vacancy data are increasingly being used by researchers to study labor market dynamics (Sahin et al. 2014, Lazear and Spletzer 2012, Faberman and Mazumder 2012, Rothwell 2012, Bagues and Labini 2009, and Kuhn and Skuterud 2004). Aggregate measures are collected from software that parses the text contained in millions of job ads posted online. These vacancy data allow analysis at a greater frequency and at more refined geographies than traditional employer surveys such as the Job Opening and Labor Turnover Survey (JOLTS). ${ }^{5}$ Although online vacancy postings do not capture all job openings, a recent report from Georgetown University estimates that between 60 and 70 percent of posted job openings are now posted online (Carnevale, Jayasundera, and Repnikov 2014). Moreover, online job ads exhibit similar trends and are closely correlated with employer surveys over time (Templin and Hirsch 2013).

\section{Burning Glass Technologies Labor/Insight Data}

Burning Glass Technologies (BGT) is one of the leading vendors of online job ads data. Their Labor/Insight analytical tool contains detailed information on the more than seven million online job openings updated daily from over 15,000 sources, including job boards, newspapers, and employer sites. The data are collected via a web crawling technique that uses computer programs called "spiders" to browse online job boards and other web sites and then systematically parse each job ad into usable data elements. BGT mines over 70 job characteristics from free-text job postings, including employer, location, job title, occupation, years of experience, and level of education required or preferred by the employer. Therefore, these data allow geographical analysis of occupation-level labor demand by education level and experience level.

The collection process employed by BGT has been developed over time to provide a robust representation of hiring, including job activity posted by small employers. For example, the collection process follows a fixed schedule, web crawling a pre-determined basket of websites that is carefully monitored and updated to include the most current and complete set

\footnotetext{
${ }^{5}$ JOLTS is a monthly survey of employers that was developed to provide information on job openings, hires, and separations. Each month the JOLTS sample comprises approximately 16,000 businesses drawn from 8 million establishments represented in the Quarterly Census of Employment and Wages. The publicly available online data provide a measure of labor demand across broad industry classifications at the national level or overall aggregate labor demand for four quadrants of the United States (at the lowest level of geography available).
} 
of online postings. In addition, BGT has developed algorithms to eliminate duplicate ads for the same job posted on both an employer website and a large job board by identifying a series of identically parsed variables across job ads such as location, employer, and job title. Finally, to avoid large fluctuations over time, BGT places more weight on large job boards than on individual employer sites, which are updated less frequently. The Labor/Insight analytical tool enables us to access the underlying job postings to validate many of the important components of this data source, including timeframes, de-duplication, and aggregation.

\section{Skill and Labor Market Measures}

Using BGT's Labor/Insight analytical tool, we collected data on a sample of occupations from the middle of the skill distribution, where it appears employer requirements may be rising, as indicated earlier by Figure 1. Specifically, we collected data for a sample of 74 occupations at the six-digit Standard Occupation Code (SOC) level by state for three points in time: 2007, 2010, and 2012. ${ }^{6}$ These occupations were chosen from a sample of 272 middle-skill occupations identified as employing an intermediate share of individuals with some college or an associate's degree based on data from the American Community Survey (ACS) prior to 2007.7 These occupations were also selected based on the density of postings in the dataset; however they were not selected based on changing requirements over the data period. In total, our sample represents 13.5 million vacancies or approximately 32 percent of the total number of postings for these three years.

Table 1 provides descriptive statistics for the variables constructed from the BGT data for our sample of 74 middle-skill occupations. Observations are occupation/state/year cells unless otherwise noted. Typically there are roughly 1,200 postings on average for a given occupation/state cell in each of the three years for which we have collected data, with fewer

\footnotetext{
${ }^{6}$ BGT does not provide data prior to 2007, and no data are available for the intervening years of 2008 and 2009.

7 Following Modestino 2010, we identified 272 "middle-skill" occupations, using data on the educational attainment of workers in those occupations from the 2005-2007 American Community Survey. Specifically, middle-skill occupations are those with at least 40 percent of workers having a high school degree, some college, or an associate's degree. Of those, we collected data from BGT on 74 occupations having the largest employment levels during that period. Examples include sales representatives, customer service representatives, administrative assistants, security guards, medical assistants, and construction managers. Unfortunately, the ACS does not have direct data on relevant work experience.
} 
total postings observed during the height of the Great Recession in 2010. It should be noted that these data exhibit a considerable amount of variation given the different employment levels of these occupations, even at the six-digit occupation level. The number of underlying observations available to construct some state/occupation/year cells varies from as few as one posting to as many as 60,000 postings at this level of disaggregation. To ensure that our dependent variables are capturing meaningful differences over time and accurately represent the state of the labor market, we drop observations with fewer than 15 total postings in a given occupation/state/year cell, which corresponds to dropping 5 percent of the sample. In addition, since we are analyzing changes in the fraction of postings requiring a particular skill, we weight the state-occupation observations by the occupation's share of total openings in the state in a given time period. This ensures that our results are not driven by outlier occupations with few underlying postings.

We constructed a range of dependent variables of interest that measure the percentage point change in the share of online job postings along two dimensions of skill: education and years of experience. All variables are constructed by state, occupation, and year. Our education categories of interest are defined in terms of the share of postings requesting a bachelor's degree or higher. ${ }^{8}$ Experience is defined in the BGT data using the following categories: $>0$ but $\leq 2$ years, $>2$ years but $\leq 5$ years, $>5$ years but $<8$ years, and $\geq 8$ years. Using the midpoint of these categories we also created a variable measuring the average years of experience. Note that the education and experience measures are increasing in all three years, with a sharp increase between 2007 and 2010 during the Great Recession.

Despite being drawn from the middle of the skill distribution, our sample shows quite a bit of heterogeneity in terms of the degree to which employer requirements have shifted over time. Figure 2 indicates that among this set of occupations, the change in the share of employers requiring a bachelor's degree or higher ranged from approximately zero to 35 percentage points

\footnotetext{
${ }^{8}$ For education, some job postings in our sample express both a minimum ("required") and maximum requested ("preferred") educational qualification. For example, approximately 12 percent of job postings specify both a bachelor's and a graduate degree in the original job posting. In response, we created two measures of requested educational qualifications: one identifying the minimum educational qualification requested and the other using the maximum. The results in all of our baseline specifications are qualitatively similar for the two measures; consequently, we use the maximum requested education qualification for the specifications presented.
} 
between 2007 and 2012. Likewise, the change in the share of employers requiring more than two years of experience exhibited a similar range, with the share falling slightly for a handful of occupations and increasing by as much as 30 percentage points for others during this period.

In addition, Figure 2 shows that changes in the share of employers requiring a higher level of education are positively correlated with those requiring more years of experience, although not perfectly so. Occupations with large increases across both dimensions of skill include fashion designers, commercial and industrial designers, business operations specialists, purchasing agents, as well as various categories of middle managers. Occupations at the opposite end of the spectrum that experienced little or no increase in skill requirements include waiters and waitresses, massage therapists, merchandise displayers, and hotel/motel desk clerks. Yet some of the occupations with the greatest increase in years of experience are those that typically require only a high school degree (for example, tool and dye makers, chefs and head cooks), while others experienced large increases in educational requirements with a modest increase in experience (for example, preschool teachers). Similarly, the relationship between the initial share of employers requiring a particular skill and the increase observed between 2007 and 2012 is also positively correlated, but not perfectly so, suggesting there are pre-existing differences across occupations that are important to take into account.

Our basic empirical strategy is to explore the relationship between changes in employer skill requirements and changes in local labor market conditions during the Great Recession and subsequent recovery. Table 1 reports descriptive statistics for several alternative measures we have assembled to capture the variation in the availability of labor across states. ${ }^{9}$ Our initial independent variable is the change in the state unemployment rate as reported by the Bureau of Labor Statistics. Figure 3 confirms that there is considerable variation across states and our two time periods to provide sufficient identification by geography over time. We also construct an analogous variable from the American Community Survey measuring the state unemployment rate for (1) individuals with a bachelor's degree or higher and (2) individuals age 35 years or

\footnotetext{
${ }_{9}$ See Appendix Table A1 for a matrix showing the correlation across the various labor supply variables for both the level and the change over time.
} 
older as a proxy to better capture changes in the available labor supply of individuals with higher levels of education and experience.

We also construct a measure of labor supply that varies by state and broad occupation group. Specifically, we construct supply/demand indices measuring the ratio of the number of unemployed individuals to the number of job postings by state for six broad occupation groups. The number of unemployed individuals is estimated using the American Community Survey, while the number of total job postings is calculated using data from both BGT and HWOL. ${ }^{10}$ Although the two indices differ in terms of the level of slack they indicate for a given occupation/state/year cell, they capture movements over time that are very similar.

We also employ additional covariates that we use to control for omitted factors and instrument for changes in the unemployment rate. To control for heterogeneity in the preexisting pool of skilled labor available to employers, our baseline controls include the share of the state population with a bachelor's degree in 2000 and the share of the state population older than 35 years of age in 2000. Our baseline controls also include the share of openings requiring a particular skill in 2007 (for example, bachelor's degree or more than two years of experience) to account for the variation in the initial level of skill required across occupations within a state as well as the change in total openings from 2007 to 2012 as a share of employment in 2007, to control for the different propensities in turnover across occupations. Finally, we employ a housing supply elasticity measure constructed by Saiz (2010), based on the share of undevelopable land and housing regulations, to instrument for changes in the state unemployment rate. This instrument is shown in Mian and Sufi (2014) to have been a powerful, predetermined predictor of poor labor market performance during the 2007-2009 recession.

\footnotetext{
${ }^{10}$ HWOL provides state-level measures of labor demand at the six-digit SOC level. HWOL is slightly different from BGT in that the program collects job postings from a smaller subset of sources, using vacancies posted directly on internet job boards and online newspaper ads, but not those posted on corporate websites.
} 


\section{Empirical Methodology and Baseline Results}

As discussed above, we propose to test (1) whether there is an increase in the education or experience requirements in job postings and (2) whether this increase (if one exists) is linked to the availability of skilled workers. Specifically, we begin by running regressions of the form:

$$
\Delta \% \text { Vacancies Requiring Skill } S_{i, j, t}=\alpha+\beta \Delta \text { Unemployment }_{j t}+\tau_{t}+e_{i j t},
$$

where $i$ represents an occupation, $j$ represents a location, and $t$ represents time. Here we pool two periods of changes: changes during the Great Recession (2007-2010) and changes during the subsequent recovery (2010-2012), where $\tau$ is a dummy for the Great Recession period. The coefficient of interest is $\beta$, the increase in skill requirements related to changes in the business cycle. A larger $\beta$ suggests more opportunistic upskilling in requirements on the part of employers. A small $\beta$, or one that is statistically indistinguishable from zero, suggests that upskilling is not related to employer attempts to capitalize on weak labor markets by selecting workers with more education or experience.

\section{Baseline Results}

Table 2 reports the results of these initial regressions for various measures of employer requirements of education and experience levels. Note that the share of employers not specifying an education or experience requirement decreased significantly in states where there was a greater increase in the unemployment rate, resulting in a negative $\beta$, as would be consistent with upskilling. In almost all of the other specifications, $\beta$ is positive and statistically significant, indicating that there was an increase in the share of jobs requiring skilled workers across education and experience measures during both periods. ${ }^{11}$ The only exception is the specification measuring the share of employers requiring a graduate degree, which yields no significant result, yet there is little variation over time in this measure, which is plausible given that we have restricted our attention to middle-skill jobs.

\footnotetext{
11 These basic results are robust to the various weighting schemes we have used such as weighting observations by the minimum number of total openings in both periods and dropping from our sample observations for which there are fewer than 75 openings for a given occupation/state cell in either period.
} 
Interestingly, the magnitude of the effect varies across our education and experience measures. Among the education measures, the effect is strongest for postings where a bachelor's degree is required or preferred. Similarly, the strongest effect among the experience measures is for postings requiring two to five years of experience, and the effect decreases for higher experience requirements. A natural concern is whether these results reflect a uniform increase in skill requirements or a combination of some employers' upskilling while at the same time others might be downskilling. However, there is also a positive and significant effect for measures that include other skill categories, such as the average years of experience observed across all postings. ${ }^{12}$ Going forward, our primary dependent variables will include other categories to allow for shifting across categories in either direction.

Although these basic results are intriguing, there are clearly a number of other factors that likely play a role in changing employer requirements over time. For example, particular occupations may be more likely to exhibit upskilling either because they are more complementary with skill-biased technological change or because they are extremely specialized and post few openings. In addition, occupations that initially had a high share of employers requiring greater levels of skill may experience smaller increases over time, as such occupations may inherently require a high degree of skill and so may already have high concentrations of highly skilled workers, leaving less scope for upskilling. And finally, it may be that particular states have a larger pool of skilled labor that employers can draw from, regardless of the state of the labor market.

To control for these additional factors, we estimate $\beta$ for specifications that include time and occupation fixed effects as well as additional covariates. Table 3 reports coefficients using our two primary dependent variables of interest: the share of employers requiring a bachelor's degree or higher and the share requiring two or more years of experience. ${ }^{13}$ Columns (1)-(2)

\footnotetext{
${ }^{12}$ Unfortunately we cannot construct an analogous measure for education, as a job posting will often require one level of education, while also stating that a higher level of education is preferred.

${ }^{13}$ Our education measure captures the share of employers requiring a bachelor's degree or higher as the maximum education level for a given job posting. However, the results are very similar in magnitude and significance if instead we base our measure on the share of employers requiring a bachelor's degree or higher as the minimum education level for a given job posting.
} 
and (7)-(8) show that controlling for occupation fixed effects significantly increases the explanatory power of the model but does little to change the magnitude or significance of our initial results. Similarly, adding in additional controls confirms our intuition around these variables without having much impact on the basic relationship between employer skill requirements and the business cycle. All else being equal, we observe less upskilling in occupations with a higher initial share of employers that require a particular skill or experience greater turnover. In addition, states where the pre-existing composition of the population in 2000 includes a higher share of individuals with a bachelor's degree or a higher share of individuals who are older (experienced) are places where we observe greater upskilling within occupations.

To give a sense of the magnitude of these results, Figure 4 plots the change in employer requirements versus the change in the unemployment rate by state for our sample of middleskill occupations. Note that the magnitude of the effect is somewhat larger for experience than for education requirements. Our baseline estimates indicate that a 1 percentage point increase in the state unemployment rate raises the share of jobs requiring a bachelor's degree by 0.5 percentage points and increases the fraction of openings requiring two or more years of experience by 0.8 percentage points. ${ }^{14}$

How large is this effect in terms of importance? In the context of the most recent downturn, our results imply that the nationwide increase in unemployment rates between 2007 and 2010 raised education and experience requirements within middle-skill occupations by 2.2 percentage points and 3.5 percentage points, respectively. For comparison, roughly one-third of the jobs in Massachusetts in our sample require a bachelor's degree compared with 16 percent of the jobs in these occupations in Arkansas. The nationwide increase in education requirements between 2007 and 2010 thus represents roughly 1/8 ${ }^{\text {th }}$ of this cross-state gap. For experience, a similar calculation shows that changes in nationwide employer requirements during this period represent more than a quarter of the cross-state gap.

\footnotetext{
14 Note that if we split our sample into two separate time periods, the relationship between the state of the labor market and employer requirements is strongest during the period around the Great Recession, 2007-2010. See Table A3 for details.
} 


\section{Using Alternative Measures of Labor Supply}

Although our baseline results demonstrate a significant and positive relationship between employer skill requirements and the state unemployment rate, it could still be the case that our broad measure of state labor market conditions reflects changes in labor demand that do not affect the supply of skilled labor. For example, the state unemployment rate encompasses individuals of all levels of skill and in fact is more likely to represent individuals who are less educated or experienced, as these individuals have a higher probability of unemployment. To better capture the availability of skilled labor we also make use of alternative measures of labor supply including state unemployment rates for individuals with a bachelor's degree or higher as well as individuals who are age 35 years or older. We also construct supply/demand indices at the state level for six broad occupation groups measured as the ratio of the number of unemployed individuals to the number of postings, using data from both HWOL and BGT. ${ }^{15}$

Table 4 reports the results using our alternative measures of labor supply for our preferred specification that includes occupation fixed effects as well as our other covariates. The variables are standardized to have a mean of zero and a standard deviation of one so that the coefficients can be compared across the various measures. The results are positive and significant across all our measures of labor market slack, although the normalized slope is larger for the unemployment rate measures than for the supply/demand indices. Comparing the unemployment rate measures, the magnitude of the coefficients is slightly greater for those specific to individuals with greater education or potential experience levels. Similarly, the two supply/demand indices yield coefficients that are similar in magnitude and significance but somewhat stronger for the BGT measure.

\footnotetext{
${ }^{15}$ HWOL publishes monthly a state-level supply and demand rate, expressed as the number of unemployed workers (as reported by the BLS) per advertised vacancy. We replicate this measure using their data on new advertised vacancies by state and broad occupation group (six broad occupation groups in total). We estimate the number of unemployed workers at the state/broad occupation group level using the American Community Survey divided by an average of the monthly number of vacancies reported for each state/broad occupation group. This measure is replicated, using the total number of vacancies in Burning Glass for each state/broad occupation group divided by 12 , to create the BGT index.
} 
Despite these additional controls, the apparent relationship between labor supply and changing skill requirements we observe may be spurious. For example, rising skill requirements may be driven not by labor supply, but by correlated changes in the demand for skilled labor. The construction of the supply/demand indices provides us with the opportunity to control for local demand shocks by making use of the variation within states across broad occupation groups by including state fixed effects in our regressions. Table 5 reports the coefficients from this exercise using our supply/demand indices calculated from HWOL and BGT. Despite these controls, we still see a positive and significant relationship between changes in employer requirements and looser labor market conditions. Thus, even with controls for the aggregate state of the local economy, local labor supply increases remain correlated with rising skill requirements.

\section{Robustness Checks: Addressing Omitted Variable Bias and Reverse Causality}

Although the specification and results above indicate a positive correlation between changes in employer requirements for skill and the availability of skilled labor, we still need to address two econometric concerns to reliably establish a causal relationship. Specifically, changes in the availability of skilled workers across states and occupations are likely to be endogenous, and reliable estimates require tests to address the possibility of omitted variable bias and reverse causality.

\section{A. Omitted Variable Bias}

A natural worry is that changes in labor supply are correlated with changes in labor demand and that insufficiently controlling for labor demand shifts may result in upwardly biased estimates. For example, suppose there are two kinds of barista positions: (1) Starbucks, which requires fine arts M.A.s so their baristas can chat about music, and (2) Dunkin Donuts, which has no education requirement. A local recession might differentially reduce coffee purchases by Dunkin Donuts customers. If that were the case, then skill requirements for 
baristas would be correlated with unemployment, but the channel would be demand, not labor supply.

To test this, we compare the relationship between employer requirements and the supply of skilled workers for nontraded industries versus traded industries that are less subject to local demand shocks. Specifically, we split our sample and explore upskilling in occupations where the share of employment in traded industries is above the median in our sample, typically reflecting occupations commonly found in industries like agriculture, mining, and manufacturing. The results reported in Table 6 show that upskilling has occurred across both traded and nontraded industries, suggesting that our results are not driven by changes in local demand conditions. In fact, there appears to be a stronger correlation between employer requirements and the cyclical component in the traded industries than in the nontraded industries, but this difference is not statistically significant.

\section{B. Reverse Causality}

Additionally, one might worry about reverse causality. Although it is unlikely, increasing employer skill requirements could be causing higher unemployment. To address this possibility, we instrument for the unemployment rate using a housing supply elasticity constructed by Saiz (2010) and aggregated to the state level in Ganong and Shoag (2012). Table 7 shows that the cyclical component related to experience requirements remains positive and significant, even when we instrument for changes in labor market conditions.

As an additional check, one can also examine the relationship between changes in employer requirements and changes in wages. If changes in employer requirements were driven by changes in the demand for skilled workers, rather than by an increase in their supply, then we would observe an increase in the skilled wage premium. The first four columns of Table 8 report the coefficients from regressing the log change in the skilled wage premium on the change in employer requirements. Here we are measuring the change in the skilled wage premium as the difference between $\log$ hourly wages at the $75^{\text {th }}$ percentile and the $25^{\text {th }}$ percentile by state and occupation. The results demonstrate that once we control for occupation 
fixed effects, there is no statistically or economically significant relationship between changing employer requirements and changes in the skilled wage premium during the two periods we examine.

Alternatively, it might be the case that employers hire additional skilled workers, changing the composition of their workforce, but with no change in the wage premium. If this were the case, then we would expect mean hourly wages to rise with an increase in the share of skilled workers. The last four columns of Table 8 report the coefficients from regressing the log change in the mean hourly wage on the change in employer requirements. Again, we find no significant relationship between changing employer requirements and changes in mean hourly wages.

Interestingly, there is a relationship between changing employer requirements and the initial skill premium within an occupation. Table 9 includes the 2007 hourly wage premium within an occupation as a control in our earlier baseline regressions. The results in columns 1 and 3 show a positive and statistically significant relationship between the initial skill premium and the change in the share of employers requiring a bachelor's degree or more than two years

of experience, suggesting that upskilling is more prevalent within occupations that place a greater premium on skilled workers. The addition of the interaction term between the initial skill premium with the state of the labor market in columns 2 and 4 reveals that upskilling related to education requirements occurred largely within high-skill-premium occupations in states with a greater availability of unemployed labor. Conversely, upskilling related to experience requirements was not limited to occupations with initially high premiums for skill.

\section{Identification Using a Natural Experiment: Troop Withdrawals from Iraq and Afghanistan}

As a source of exogenous variation, we make use of a natural experiment using large troop withdrawals from Iraq and Afghanistan between 2009 and 2012. According to a report by the Congressional Research Service, the number of troops in Afghanistan and Iraq increased from 5,200 in FY2002 to a peak of 187,900 in FY2008, primarily because of increases in troop deployments in Iraq, beginning with the invasion in March 2003 (Belasco 2009). In FY2009, the 
United States began withdrawing troops from Iraq, although total troop strength abroad remained largely the same, due to increases in Afghanistan. By FY2012, the United States had withdrawn from Iraq, and overall troop strength for the two wars had declined to 67,500 .

To capture the exogenous variation in labor supply related to troop withdrawals from Iraq and Afghanistan, we use the American Community Survey to estimate the change in the number of post-9/11 veterans in the labor force at the state level each year from 2007 through 2012. At the height of the troop withdrawal from Iraq, an additional 200,000 to 300,000 post-9/11 veterans returned home each year between 2009 and 2012. We then construct the state-level veteran supply shock as the change in number of veterans for a given time period, and express this change as a share of total postings for each state and occupation observation. Yet veteran employment is concentrated among a select group of occupations that typically make use of the specialized skill set that comes from serving in the military. To better capture the impact of the increase in the supply of post-9/11 veterans, we also include specifications that interact the state level veteran supply shock with the veteran share of employment in a given occupation.

As a first pass, we include a measure of the state-level veteran supply shock in our model for our pooled sample of 74 occupations. Table 10 demonstrates that there is a significant and positive relationship between the veteran supply shock and the change in employer requirements. This is true even when controlling for state fixed effects to account for local demand shocks. Not surprisingly, the relationship is greater in significance when we interact the veteran supply shock with the veteran share of occupation employment. How do these results compare with our state fixed effects specifications using the BGT supply/demand index listed in Table 5? Using the average unemployment rate for post-9/11 veterans during this period, we re-scale the dependent variable to reflect the annual change in the number of unemployed veterans, analogous to the numerator in our earlier supply/demand indices. Doing so yields a coefficient of 1.8 for the change in education requirements and 1.5 for the change in experience-similar to the magnitude of the effect related to increasing the supply of unemployed persons in the general population for education and roughly two-thirds of the magnitude for experience. 


\section{Conclusion}

While the unemployment rate for low-skilled workers is typically higher than that for the college-educated, during recessions low-skilled workers tend to fare even worse. One potential explanation that has been suggested for the differential impact of the Great Recession is the ability of unemployed, high-skilled workers to take middle- and low-skilled jobs during the downturn.

This paper demonstrates and quantifies this opportunistic upskilling by employers. Using data from online job vacancy postings, we examine changes in employer requirements across occupations and locations during the course of the Great Recession (2007-2010) and subsequent recovery (2010-2012). We find that, in bad labor markets, employer requirements rise for both education and experience, even when controlling for time, occupation, and state fixed effects among other covariates. This is true when using alternative measures of labor market slack, and does not appear to be driven by reverse causality or local demand effects.

We next make use of a natural experiment using troop withdrawals from Iraq and Afghanistan as a source of exogenous variation. We find significant increases in employer requirements for occupations that typically employ veterans, but not for a set of placebo nonveteran occupations. Again, this indicates that the upskilling we observe during this period is caused by increases in the labor supply.

Our results suggest several key implications for the dynamics of the middle-skill labor market going forward. Although the lack of data prior to 2007 prevent us from directly identifying the secular trend in upskilling in our dataset, we can compare the labor market effect to the total increase in skill requirements observed for this set of occupations in our data. Our results indicate that the degree of opportunistic upskilling by employers that was related to the state of the labor market was as large as roughly one-third of the total increase in education skill requirements observed in our data between 2007 and 2010. For experience, employer upskilling related to the increased supply of labor during the business cycle accounted for more than half of the total increase in experience requirements in our dataset. 
The finding that weaker labor markets lead to rising job posting requirements has important implications for models in labor economics and macroeconomics that are aimed at explaining the dynamics of the labor market during recessions. In particular, our results indicate that much of the observed increase in skill requirements within detailed occupations is correlated with the business cycle. This is yet another piece of evidence in the literature that substantiates the notion that what is sometimes labeled as structural mismatch employment is actually at least partly cyclical. In addition, we are able to document a novel feedback mechanism between the labor supply and the selectivity of vacancies that may be relevant for macroeconomic models with heterogeneous workers and welfare analysis.

Our findings also have implications for the evolution of skill requirements in middleskill jobs going forward as the economy recovers, shedding light on the persistence of the increased skill demand that has been observed within occupations. For example, perhaps the greater sensitivity of experience requirements to changes in the labor supply implies that these requirements are more likely to revert as the labor market tightens-possibly helping to reduce the relatively high rate of unemployment for younger, less-experienced workers. The question of persistence is particularly relevant for younger workers just entering the labor market who are likely to be less skilled and experienced-particularly at a time when employers seem less willing to provide on-the-job training. As the labor market continues to recover, states may want to consider filling that gap by sponsoring additional internships and apprenticeships that help younger workers gain the skills and experience now required by employers for entry into middle-skill jobs.

\section{References}

Albrecht, James, and Susan Vroman. 2002. "A Matching Model with Endogenous Skill Requirements" International Economic Review 43.1 (2002): 283-305.

Autor, David H., Lawrence F. Katz, and Melissa S. Kearney. 2008. "Trends in U.S. wage Inequality: Revising the Revisionists." The Review of Economics and Statistics 90.2: 300-323.

Autor, David H., and David Dorn. 2013. "The Growth of Low-Skill Service Jobs and the Polarization of the U.S. Labor Market." American Economic Review 103(5): 1553-1597. 
Bagues, Manuel F., and Mauro S. Labini. 2009. "Do On-line Labor Market Intermediaries Matter? The Impact of Almalaurea on the University-to-Work Transition." In Studies of Labor Market Intermediation, ed. David H. Autor, 127-154. Chicago: University of Chicago Press.

Beaudry, Paul, David A. Green, and Benjamin M. Sand. 2013. "The Great Reversal in the Demand for Skill and Cognitive Tasks." Working Paper 18901. Cambridge, MA. National Bureau of Economic Research.

Belasco, Amy. 2009. "Troop Levels in the Afghan and Iraq Wars, FY2001-FY2012: Cost and Other Potential Issues." Washington, DC. Congressional Research Service. CRS Report for Congress No. R40682.

Carnevale, Anthony, Tamara Jayasundera, and Ban Cheah. 2012. The College Advantage: Weathering the Economic Storm. Washington, DC: Georgetown University Center on Education and the Workforce.

Carnevale, Anthony, Tamara Jayasundera, and Dimitri Repnikov. 2012. Understanding Online Job Ads Data. Washington, DC: Georgetown University Center on Education and the Workforce.

Charles, Kerwin Kofi, Erik Hurst, and Matthew J. Notowidigdo. 2013."Manufacturing Decline, Housing Booms, and Non-Employment." Working Paper No. 18949. Cambridge, MA: National Bureau for Economic Research.

Davis, Stephen J., Jason Faberman, and John C. Haltiwanger. 2012. “The Establishment-level Behavior of Vacancies and Hiring." NBER Working Paper No. 16265.

Faberman, Jason, and Bhash Mazumder. 2012. "Is There a Skills Mismatch in the Labor Market?" Federal Reserve Bank of Chicago, Essays on Issues No. 300.

Foote, Christopher, and Richard Ryan. 2012. “Labor-Market Polarization over the Business Cycle." Federal Reserve Bank of Boston Working Paper No. 12-8.

Ganong, Peter, and Daniel Shoag. "2012. "Why Has Regional Convergence in the US Stopped?" HKS Faculty Research Working Paper Series RWP 12-028. Cambridge, MA: Harvard University John F. Kennedy School of Government.

Gautier, Pieter A. 2002. "Unemployment and Search Externalities in a Model with Heterogeneous Jobs and Workers." Economica 69(273): 21-40.

Gautier, Pieter A., J. van den Berg, Jan C. van Ours, and Geert Ridder. 2002. "Worker Turnover at the Firm Level and Crowding Out of Lower Educated Workers." European Economic Review 46(3): 523-538.

Goos, Maarten, and Alan Manning. 2007. "Lousy and Lovely Jobs: The Rising Polarization of Work in Britain."The Review of Economics and Statistics 89(1): 118-133. 
Jaimovich, Nir, and Henry E. Siu. 2014. "The Trend Is the Cycle: Job Polarization and Jobless Recoveries." Working Paper No. 18334. Cambridge, MA: National Bureau of Economic Research.

Katz, Lawrence, and Kevin Murphy. 1992 “Changes in Relative Wages, 1963-1987: Supply and Demand Factors." The Quarterly Journal of Economics 107(1): 35-78.

Kuhn, Peter J., and Mikal Skuterud. 2004. "Internet Job Search and Unemployment Durations." American Economic Review 94(1): 218-232.

Lazear, Edward P., and James R. Spletzer. 2012. “The United States Labor Market: Status Quo or New Normal?" Working Paper No. 18386 Cambridge, MA: National Bureau of Economic Research.

Marinescu, Ioana, and Ronald Wolthoff. 2012. "Wages, Applications, and Skills. "Unpublished working paper. Available at http://individual.utoronto.ca/wolthoff/pdf/MarinescuWolthoff.pdf.

Merkl, Christian, and Thijs van Rens. 2012. "Selective Hiring and Welfare Analysis in Labor Market Models." Working Papers No. 1752. Kiel, Germany, Kiel Institute for the World Economy.

Mian, Atif R., and Amir Sufi. 2014. "What Explains the 2007-2009 Drop in Employment?" Econometrica Forthcoming.

Modestino, Alicia Sasser. 2010. "Mismatch in the Labor Market: Measuring the Supply of and Demand for Skilled Labor in New England." Federal Reserve Bank of Boston, New England Public Policy Center Research Report No. 10-2.

Mortensen, Dale T., and Christopher A. Pissarides. 1994. “Job Creation and Job Destruction in the Theory of Unemployment." The Review of Economic Studies, 61(3), 397-415.

Rothwell, Jonathan. 2012. "Education, Job Openings, and Unemployment in Metropolitan America." Washington, D.C.: Brookings Institution Metropolitan Policy Program.

Saiz, Albert. 2010. “The Geographic Determinants of Housing Supply." Quarterly Journal of Economics 125(3): 1253-1296.

Sahin, Aysegul, J. Song, G. Topa, and G. Violante. 2014. “Mismatch Unemployment.” American Economic Review Forthcoming.

Templin, Thomas, and Lesley Hirsch. 2013. “Do Online Job Ads Predict Hiring?” New York: New York City Labor Market Information Services.

Tüzemen, Didem, and Jonathan Willis. 2013. "The Vanishing Middle: Job Polarization and Workers' Response to the Decline in Middle-Skill Jobs." Federal Reserve Bank of Kansas City. Economic Review Q1. 
Table 1. Descriptive Statistics

\begin{tabular}{|c|c|c|c|c|c|c|c|c|c|c|c|c|c|c|c|c|}
\hline & \multicolumn{4}{|c|}{2007} & \multicolumn{4}{|c|}{2010} & \multicolumn{4}{|c|}{2012} & \multicolumn{2}{|c|}{$\Delta 2007-2010$} & \multicolumn{2}{|c|}{$\Delta 2010-2012$} \\
\hline & Mean & Std. Dev. & Min & Max & Mean & Std. Dev. & Min & Max & Mean & Std. Dev. & Min & Max & Mean & Std. Dev. & Mean & Std. Dev. \\
\hline Total Number of Job Posting Ads & $1,255.77$ & $2,984.35$ & 16.00 & $61,846.00$ & $1,179.79$ & $2,654.18$ & 16.00 & $53,968.00$ & $1,309.78$ & $2,862.22$ & 16.00 & $56,067.00$ & -75.97 & 974.35 & 136.38 & 530.30 \\
\hline \multicolumn{17}{|l|}{ Share of Postings With: } \\
\hline No Education Requirement & 74.40 & 12.34 & 20.00 & 100.00 & 58.35 & 17.78 & 2.09 & 98.75 & 52.08 & 17.56 & 4.08 & 98.91 & -16.05 & 14.26 & -6.29 & 11.55 \\
\hline Bachelor's Degree Listed as an Educ. Req. & 10.97 & 10.29 & 0.00 & 55.74 & 17.92 & 16.32 & 0.00 & 93.95 & 20.96 & 17.29 & 0.00 & 91.02 & 6.95 & 9.74 & 3.08 & 7.29 \\
\hline Graduate Degree Listed as an Educ. Req. & 3.15 & 3.74 & 0.00 & 46.82 & 5.12 & 5.59 & 0.00 & 72.50 & 5.97 & 5.93 & 0.00 & 47.76 & 1.97 & 4.72 & 0.85 & 4.71 \\
\hline Bachelor's/Graduate Degree Listed as an Educ. Req. & 12.59 & 10.92 & 0.00 & 60.66 & 20.43 & 17.41 & 0.00 & 94.90 & 24.07 & 18.31 & 0.00 & 91.02 & 7.84 & 10.51 & 3.67 & 7.94 \\
\hline \multicolumn{17}{|l|}{ Share of Postings Requiring: } \\
\hline No Experience & 72.18 & 12.06 & 17.78 & 100.00 & 55.82 & 17.24 & 8.57 & 100.00 & 52.23 & 17.34 & 4.17 & 100.00 & -16.36 & 14.93 & -3.66 & 10.99 \\
\hline Less Than Two Years of Experience & 14.25 & 7.93 & 0.00 & 62.50 & 22.75 & 11.70 & 0.00 & 82.22 & 24.93 & 12.18 & 0.00 & 83.33 & 8.50 & 10.84 & 2.20 & 8.96 \\
\hline Two to Five Years of Experience & 10.51 & 8.00 & 0.00 & 56.67 & 16.59 & 12.11 & 0.00 & 67.16 & 17.99 & 12.70 & 0.00 & 63.16 & 6.08 & 8.84 & 1.44 & 6.85 \\
\hline Five to Eight Years of Experience & 1.42 & 2.06 & 0.00 & 24.00 & 2.48 & 3.36 & 0.00 & 35.51 & 2.58 & 3.53 & 0.00 & 36.36 & 1.06 & 2.83 & 0.10 & 2.64 \\
\hline Greater Than Eight Years of Experience & 1.63 & 2.61 & 0.00 & 31.25 & 2.35 & 3.78 & 0.00 & 44.00 & 2.27 & 3.66 & 0.00 & 34.62 & 0.72 & 3.28 & -0.08 & 2.63 \\
\hline Average Years of Experience & 0.73 & 0.47 & 0.00 & 3.63 & 1.16 & 0.75 & 0.00 & 4.48 & 1.23 & 0.77 & 0.00 & 4.52 & 0.42 & 0.53 & 0.07 & 0.36 \\
\hline State Unemployment Rate & 4.34 & 0.97 & 2.60 & 7.10 & 8.79 & 2.01 & 3.80 & 13.80 & 7.33 & 1.69 & 3.00 & 11.50 & 4.45 & 1.55 & -1.45 & 0.67 \\
\hline State UR for Persons with Bachelor's Degree or Greater & 2.56 & 0.57 & 0.83 & 3.55 & 4.46 & 1.28 & 1.81 & 7.03 & 3.77 & 1.16 & 1.13 & 6.43 & 1.90 & 0.96 & -0.69 & 0.56 \\
\hline State UR for Workers Aged 35 Plus & 3.07 & 0.74 & 1.30 & 5.30 & 6.89 & 1.79 & 2.60 & 12.50 & 5.62 & 1.43 & 2.40 & 9.10 & 3.82 & 1.47 & -1.26 & 0.79 \\
\hline HWOL Broad Occupation Group Supply/Demand Rate & 5.26 & 5.29 & 0.06 & 42.78 & 8.28 & 6.57 & 0.80 & 49.24 & 5.29 & 3.64 & 0.22 & 28.02 & 3.02 & 3.44 & -3.02 & 3.47 \\
\hline BGT Broad Occupation Group Supply/Demand Rate & 10.29 & 11.40 & 0.08 & 99.09 & 14.69 & 12.60 & 1.05 & 73.76 & 10.82 & 9.01 & 0.35 & 54.08 & 4.40 & 6.92 & -3.89 & 5.97 \\
\hline Number of Observations & \multicolumn{4}{|c|}{3,357} & \multicolumn{4}{|c|}{3,357} & \multicolumn{4}{|c|}{3,376} & \multicolumn{2}{|c|}{3,357} & \multicolumn{2}{|c|}{3,376} \\
\hline
\end{tabular}


Table 2. Relationship between Changes in Employer Requirements and the Business Cycle

\begin{tabular}{|c|c|c|c|c|c|c|c|c|c|}
\hline & \multicolumn{3}{|c|}{ P.P. Change in Educ. Qualifications } & \multicolumn{5}{|c|}{ P.P. Change in Exp. Qualifications } & \multirow[b]{2}{*}{$\begin{array}{l}\text { Avg. Num. } \\
\text { of Yrs. }\end{array}$} \\
\hline & No Educ & $\begin{array}{l}\text { Bachelor's } \\
\text { Degree }\end{array}$ & $\begin{array}{c}\text { Grad./Prof. } \\
\text { Degree }\end{array}$ & No Exp. & $\begin{array}{c}>0 \text { to } \leqslant 2 \\
\text { Yrs. }\end{array}$ & $\begin{array}{c}>2 \text { to } \leqslant 5 \\
\text { Yrs. }\end{array}$ & $\begin{array}{l}>5 \text { to } \leqslant 8 \\
\text { Yrs. }\end{array}$ & $>8$ Yrs. & \\
\hline$\Delta$ State UR & $\begin{array}{c}-1.537^{* * *} \\
(0.555)\end{array}$ & $\begin{array}{c}0.615^{* * *} \\
(0.146)\end{array}$ & $\begin{array}{l}-0.0230 \\
(0.163)\end{array}$ & $\begin{array}{c}-1.556^{* * *} \\
(0.531)\end{array}$ & $\begin{array}{l}0.743^{*} \\
(0.375)\end{array}$ & $\begin{array}{c}0.661^{* * *} \\
(0.173)\end{array}$ & $\begin{array}{c}0.0867^{* * *} \\
(0.0289)\end{array}$ & $\begin{array}{l}0.0647^{*} \\
(0.0358)\end{array}$ & $\begin{array}{c}0.0414^{* * *} \\
(0.0114)\end{array}$ \\
\hline $\begin{array}{l}\text { 07-10 Period } \\
\text { Indicator }\end{array}$ & $\begin{array}{c}2.306 \\
(3.939)\end{array}$ & $\begin{array}{l}-0.741 \\
(1.106)\end{array}$ & $\begin{array}{c}0.831 \\
(1.261)\end{array}$ & $\begin{array}{l}-4.297 \\
(3.504)\end{array}$ & $\begin{array}{l}4.754^{*} \\
(2.456)\end{array}$ & $\begin{array}{l}-0.775 \\
(1.153)\end{array}$ & $\begin{array}{c}0.161 \\
(0.196)\end{array}$ & $\begin{array}{c}0.157 \\
(0.284)\end{array}$ & $\begin{array}{c}0.0434 \\
(0.0796)\end{array}$ \\
\hline Constant & $\begin{array}{c}-9.887^{* * *} \\
(1.351)\end{array}$ & $\begin{array}{c}3.845^{* * *} \\
(0.390)\end{array}$ & $\begin{array}{l}0.954^{* *} \\
(0.423)\end{array}$ & $\begin{array}{c}-4.721^{* * *} \\
(1.197)\end{array}$ & $\begin{array}{l}2.114^{* *} \\
(0.810)\end{array}$ & $\begin{array}{c}2.320^{* * *} \\
(0.386)\end{array}$ & $\begin{array}{l}0.263^{* * *} \\
(0.0660)\end{array}$ & $\begin{array}{c}0.0237 \\
(0.0978)\end{array}$ & $\begin{array}{l}0.121^{* * *} \\
(0.0280)\end{array}$ \\
\hline Adj. R-squared & 0.108 & 0.0509 & 0.00907 & 0.291 & 0.227 & 0.0812 & 0.0333 & 0.0177 & 0.155 \\
\hline Observations & 6848 & 6848 & 6848 & 6848 & 6848 & 6848 & 6848 & 6848 & 6848 \\
\hline
\end{tabular}

Source: Authors' analysis using data from Burning Glass Technologies, 2007-2012.
Notes: Sample excludes state/occupation observations with fewer than 15 total openings. Observations weighted by the occupation's share of each state's total postings. Standard errors (in parentheses) clustered by state. ${ }^{*} \mathrm{p}<0.10,{ }^{* *} \mathrm{p}<0.05,{ }^{* * *} \mathrm{p}<0.01$ 
Table 3. Relationship between the Change in Employer Requirements and the Business Cycle, with Controls

\begin{tabular}{|c|c|c|c|c|c|c|c|c|c|c|c|c|}
\hline & \multicolumn{6}{|c|}{$\begin{array}{c}\text { Change in Share of Postings Requesting } \\
\text { a Bachelor's/Graduate Degree }\end{array}$} & \multicolumn{6}{|c|}{$\begin{array}{c}\text { Change in Share of Postings Requesting } \\
>2 \text { Years Experience }\end{array}$} \\
\hline & $(1)$ & $(2)$ & (3) & $(4)$ & $(5)$ & $(6)$ & $(7)$ & $(8)$ & (9) & $(10)$ & (11) & $(12)$ \\
\hline$\Delta$ State UR & $\begin{array}{c}0.508^{* * *} \\
(0.185)\end{array}$ & $\begin{array}{l}0.475^{* *} \\
(0.185)\end{array}$ & $\begin{array}{l}0.437^{* *} \\
(0.171)\end{array}$ & $\begin{array}{l}0.460^{* *} \\
(0.184)\end{array}$ & $\begin{array}{l}0.484^{* *} \\
(0.189)\end{array}$ & $\begin{array}{l}0.440^{* *} \\
(0.170)\end{array}$ & $\begin{array}{c}0.812^{* * *} \\
(0.205)\end{array}$ & $\begin{array}{c}0.774^{* * *} \\
(0.208)\end{array}$ & $\begin{array}{c}0.802^{* * *} \\
(0.169)\end{array}$ & $\begin{array}{c}0.768^{* * *} \\
(0.206)\end{array}$ & $\begin{array}{c}0.770^{* * *} \\
(0.209)\end{array}$ & $\begin{array}{c}0.794^{* * *} \\
(0.172)\end{array}$ \\
\hline $\begin{array}{l}\text { Initial Share Req. } \\
\text { Skill }(07)\end{array}$ & & & $\begin{array}{r}-0.295^{* * *} \\
(0.0331)\end{array}$ & & & $\begin{array}{c}-0.344^{* * *} \\
(0.0213)\end{array}$ & & & $\begin{array}{r}-0.355^{* * *} \\
(0.0347)\end{array}$ & & & $\begin{array}{r}-0.359^{* * *} \\
(0.0336)\end{array}$ \\
\hline $\begin{array}{l}\Delta \text { Tot. } \\
\text { Postings, } 07-12 \text { / Tot. Emp., } 07\end{array}$ & & & & $\begin{array}{c}-2.130^{* * *} \\
(0.582)\end{array}$ & & $\begin{array}{c}-2.115^{* * *} \\
(0.656)\end{array}$ & & & & $\begin{array}{c}-1.682^{* * *} \\
(0.473)\end{array}$ & & $\begin{array}{c}-1.897^{* * *} \\
(0.450)\end{array}$ \\
\hline $\begin{array}{l}\text { Share of Pop. with } \\
\text { BD+ / Avg. Age (2000) }\end{array}$ & & & & & $\begin{array}{l}0.0772^{*} \\
(0.0455)\end{array}$ & $\begin{array}{l}0.174^{* * *} \\
(0.0378)\end{array}$ & & & & & $\begin{array}{c}0.375 \\
(0.227)\end{array}$ & $\begin{array}{c}0.270 \\
(0.205)\end{array}$ \\
\hline Occ Fixed Effects & & $\mathrm{X}$ & $\mathrm{X}$ & $\mathrm{X}$ & $\mathrm{X}$ & $\mathrm{X}$ & & $\mathrm{X}$ & $\mathrm{X}$ & $\mathrm{X}$ & $\mathrm{x}$ & $\mathrm{X}$ \\
\hline Adj. R-squared & 0.0436 & 0.269 & 0.302 & 0.273 & 0.271 & 0.315 & 0.0915 & 0.325 & 0.371 & 0.328 & 0.326 & 0.376 \\
\hline Observations & 6848 & 6848 & 6848 & 6733 & 6848 & 6733 & 6848 & 6848 & 6848 & 6733 & 6848 & 6733 \\
\hline
\end{tabular}


Table 4. Relationship between the Change in Employer Requirements and the Business Cycle, Using Alternative Measures of Supply

\begin{tabular}{|c|c|c|c|c|c|c|c|c|}
\hline & \multicolumn{4}{|c|}{$\begin{array}{c}\text { Change in Share of Postings Requesting } \\
\text { a Bachelor's/Graduate Degree }\end{array}$} & \multicolumn{4}{|c|}{$\begin{array}{c}\text { Change in Share of Postings Requesting } \\
>2 \text { Years Experience }\end{array}$} \\
\hline & (1) & $(2)$ & (3) & (4) & $(5)$ & (6) & $(7)$ & $(8)$ \\
\hline$\Delta$ State UR & $\begin{array}{c}0.181^{* *} \\
(0.0702)\end{array}$ & & & & $\begin{array}{l}0.305^{* * *} \\
(0.0708)\end{array}$ & & & \\
\hline $\begin{array}{l}\Delta \text { State UR for } \\
\mathrm{BD}+/ \text { Workers Aged } 35+\end{array}$ & & $\begin{array}{l}0.215^{* * *} \\
(0.0492)\end{array}$ & & & & $\begin{array}{l}0.300^{* * *} \\
(0.0446)\end{array}$ & & \\
\hline $\begin{array}{l}\Delta \text { HWOL Sup/Dem } \\
\text { Rate }\end{array}$ & & & $\begin{array}{c}0.0661^{* * *} \\
(0.0234)\end{array}$ & & & & $\begin{array}{l}0.110^{* * *} \\
(0.0244)\end{array}$ & \\
\hline $\begin{array}{l}\triangle \text { BGT Sup/Dem } \\
\text { Rate }\end{array}$ & & & & $\begin{array}{l}0.105^{* * *} \\
(0.0304)\end{array}$ & & & & $\begin{array}{l}0.135^{* * *} \\
(0.0289)\end{array}$ \\
\hline Baseline Controls & $\mathrm{X}$ & $\mathrm{X}$ & $\mathrm{X}$ & $\mathrm{X}$ & $\mathrm{X}$ & $\mathrm{X}$ & $\mathrm{X}$ & $\mathrm{X}$ \\
\hline Occ Fixed Effects & $\mathrm{X}$ & $\mathrm{X}$ & $\mathrm{X}$ & $\mathrm{X}$ & $\mathrm{X}$ & $\mathrm{X}$ & $\mathrm{X}$ & $\mathrm{X}$ \\
\hline Adj. R-squared & 0.315 & 0.323 & 0.312 & 0.317 & 0.354 & 0.366 & 0.346 & 0.351 \\
\hline Observations & 6733 & 6733 & 6733 & 6733 & 6733 & 6733 & 6733 & 6733 \\
\hline
\end{tabular}

Source: Authors' analysis using data from Burning Glass Technologies, 2007-2012.

Notes: Reported coefficients are standardized. See data appendix for discussion on the creation of the HWOL and BGT broad occupation group supply/demand rates. All specifications include a control for differences between the two time periods, 2007-2010 and 2010-2012. Sample excludes state/occupation observations with fewer than 15 total openings. Observations weighted by the occupation's share of each state's total postings. Standard errors (in parentheses) clustered by state. ${ }^{*} \mathrm{p}<0.10,{ }^{* *} \mathrm{p}<0.05,{ }^{* * *} \mathrm{p}<0.01$ 
Table 5. Relationship between the Change in Employer Requirements and the Business Cycle, Including State Fixed Effects

\begin{tabular}{|c|c|c|c|c|c|c|c|c|c|c|c|c|}
\hline & \multicolumn{6}{|c|}{$\begin{array}{l}\text { Change in Share of Postings Requesting } \\
\text { a Bachelor's/Graduate Degree }\end{array}$} & \multicolumn{6}{|c|}{$\begin{array}{l}\text { Change in Share of Postings Requesting } \\
>2 \text { Years Experience }\end{array}$} \\
\hline & (1) & $(2)$ & (3) & (4) & (5) & (6) & (7) & (8) & (9) & $(10)$ & (11) & (12) \\
\hline $\begin{array}{l}\Delta \text { in HWOL } \\
\text { Sup/Dem Rate }\end{array}$ & $\begin{array}{l}0.142^{* * *} \\
(0.0503)\end{array}$ & $\begin{array}{l}0.169^{* * *} \\
(0.0626)\end{array}$ & $\begin{array}{c}0.180^{*} \\
(0.0943)\end{array}$ & & & & $\begin{array}{l}0.262^{* * *} \\
(0.0526)\end{array}$ & $\begin{array}{l}0.197^{* * *} \\
(0.0643)\end{array}$ & $\begin{array}{c}0.219^{* *} \\
(0.0959)\end{array}$ & & & \\
\hline $\begin{array}{l}\Delta \text { in BGT } \\
\text { Sup/Dem Rate }\end{array}$ & & & & $\begin{array}{l}0.136^{* * *} \\
(0.0392)\end{array}$ & $\begin{array}{l}0.126^{* *} \\
(0.0503)\end{array}$ & $\begin{array}{c}0.152^{*} \\
(0.0810)\end{array}$ & & & & $\begin{array}{l}0.182^{* * *} \\
(0.0372)\end{array}$ & $\begin{array}{l}0.145^{* * *} \\
(0.0450)\end{array}$ & $\begin{array}{l}0.178^{* *} \\
(0.0739)\end{array}$ \\
\hline Baseline Controls & $\mathrm{X}$ & $\mathrm{X}$ & & $\mathrm{X}$ & $\mathrm{X}$ & & $\mathrm{X}$ & $\mathrm{X}$ & & $\mathrm{X}$ & $\mathrm{X}$ & \\
\hline Occ Fixed Effects & $\mathrm{X}$ & $\mathrm{X}$ & & $\mathrm{X}$ & $\mathrm{X}$ & & $\mathrm{X}$ & $\mathrm{X}$ & & $\mathrm{X}$ & $\mathrm{X}$ & \\
\hline State Fixed Effects & & $\mathrm{X}$ & & & $\mathrm{X}$ & & & $\mathrm{X}$ & & & $\mathrm{X}$ & \\
\hline State*Occ FE & & & $\mathrm{X}$ & & & $\mathrm{X}$ & & & $\mathrm{X}$ & & & $\mathrm{X}$ \\
\hline Adj. R-squared & 0.312 & 0.335 & -0.135 & 0.317 & 0.337 & -0.128 & 0.368 & 0.395 & -0.0432 & 0.373 & 0.398 & -0.0342 \\
\hline Observations & 6733 & 6733 & 6733 & 6733 & 6733 & 6733 & 6733 & 6733 & 6733 & 6733 & 6733 & 6733 \\
\hline
\end{tabular}

Notes: See data appendix for discussion on the creation of the HWOL and BGT broad occupation group supply/demand rates. All specifications include a control for differences between the two time periods, 2007-2010 and 2010-2012. Sample excludes state/occupation observations with fewer than 15 total openings. Observations weighted by the occupation's share of 
Table 6. Relationship between the Change in Employer Requirements and the Business Cycle, Traded vs. Nontraded Industries

\begin{tabular}{|c|c|c|c|c|c|c|}
\hline & \multicolumn{3}{|c|}{$\begin{array}{c}\text { Change in Share of Postings Requesting a } \\
\text { Bachelor's/Graduate Degree }\end{array}$} & \multicolumn{3}{|c|}{$\begin{array}{l}\text { Change in Share of Postings Requesting } \\
\qquad 2 \text { Years Experience }\end{array}$} \\
\hline & $>$ Median & $<$ Median & Pooled Samp. & $>$ Median & $<$ Median & Pooled Samp. \\
\hline$\Delta$ State UR & $\begin{array}{c}0.719^{* * *} \\
(0.215)\end{array}$ & $\begin{array}{l}0.0353 \\
(0.137)\end{array}$ & $\begin{array}{l}0.412^{* *} \\
(0.173)\end{array}$ & $\begin{array}{c}1.053^{* * *} \\
(0.235)\end{array}$ & $\begin{array}{c}0.418^{* * *} \\
(0.110)\end{array}$ & $\begin{array}{c}0.810^{* * *} \\
(0.171)\end{array}$ \\
\hline $\begin{array}{l}\text { (Traded } \\
\text { Share })^{*}(\Delta \text { State UR })\end{array}$ & & & $\begin{array}{c}0.121 \\
(0.137)\end{array}$ & & & $\begin{array}{c}-0.0691 \\
(0.120)\end{array}$ \\
\hline Baseline Controls & $\mathrm{X}$ & $\mathrm{X}$ & $\mathrm{X}$ & $\mathrm{X}$ & $\mathrm{X}$ & $\mathrm{X}$ \\
\hline Occ Fixed Effects & $\mathrm{X}$ & $\mathrm{X}$ & $\mathrm{X}$ & $\mathrm{X}$ & $\mathrm{X}$ & $\mathrm{X}$ \\
\hline Adj. R-squared & 0.331 & 0.246 & 0.315 & 0.415 & 0.291 & 0.376 \\
\hline Observations & 3485 & 3248 & 6733 & 3485 & 3248 & 6733 \\
\hline
\end{tabular}

Source: Authors' analysis using data from Burning Glass Technologies, 2007-2012.

Notes: See data appendix for discussion on the creation of the traded/non-traded measure used above. All specifications include a control for differences between the two time periods, 2007-2010 and 2010-2012. Sample excludes state/occupation observations with fewer than 15 total openings. Observations weighted by the occupation's share of each state's total postings. Standard errors (in parentheses) clustered by state. ${ }^{*} \mathrm{p}<0.10,{ }^{* *} \mathrm{p}<0.05, * * * \mathrm{p}<0.01$ 
Table 7. Relationship between the Change in Employer Requirements and the Business Cycle, IV Estimates for Reverse Causality

\begin{tabular}{|c|c|c|c|c|}
\hline & \multicolumn{2}{|c|}{$\begin{array}{c}\text { Change in Share of Postings Requesting a } \\
\text { Bachelor's/Graduate Degree }\end{array}$} & \multicolumn{2}{|c|}{$\begin{array}{c}\text { Change in Share of Postings Requesting } \\
>2 \text { Years Experience }\end{array}$} \\
\hline & (1) & $(2)$ & (3) & $(4)$ \\
\hline$\Delta$ State UR & $\begin{array}{l}1.698^{* *} \\
(0.790)\end{array}$ & $\begin{array}{l}0.825^{*} \\
(0.463)\end{array}$ & $\begin{array}{l}1.628^{* *} \\
(0.807)\end{array}$ & $\begin{array}{c}2.026^{* * *} \\
(0.645)\end{array}$ \\
\hline Baseline Controls & & $\mathrm{X}$ & & $\mathrm{X}$ \\
\hline Occ Fixed Effects & & $\mathrm{X}$ & & $\mathrm{X}$ \\
\hline F-Test Excluded Instrument & 16.27 & 24.31 & 16.27 & 15.57 \\
\hline Observations & 6588 & 6489 & 6588 & 6489 \\
\hline
\end{tabular}

Source: Authors' analysis using data from Burning Glass Technologies, 2007-2012.

Notes: All specifications include a control for differences between the two time periods, 2007-2010 and 2010-2012. Sample excludes state/occupation observations with fewer than 15 total openings. Observations weighted by the occupation's share of each state's total postings. Standard errors (in parentheses) clustered by state. ${ }^{*} \mathrm{p}<0.10,{ }^{* *} \mathrm{p}<0.05, * * * \mathrm{p}<0.01$ 
Table 8. Relationship between the Change in Wages and Employer Requirements

\begin{tabular}{|c|c|c|c|c|c|c|c|c|}
\hline & \multicolumn{4}{|c|}{ Log Difference in the Hourly Wage Premium } & \multicolumn{4}{|c|}{ Log Difference in Mean Hourly Wage } \\
\hline & (1) & $(2)$ & (3) & $(4)$ & $(5)$ & $(6)$ & $(7)$ & $(8)$ \\
\hline$\Delta \mathrm{BA}+$ Share & $\begin{array}{c}-0.000000292 \\
(0.000159)\end{array}$ & $\begin{array}{l}-0.0000409 \\
(0.000163)\end{array}$ & & & $\begin{array}{c}0.000298 \\
(0.000181)\end{array}$ & $\begin{array}{c}0.000217 \\
(0.000197)\end{array}$ & & \\
\hline $\begin{array}{l}\Delta \text { Need } 2+\text { Yrs. } \\
\text { Exp. Share }\end{array}$ & & & $\begin{array}{c}0.000131 \\
(0.000136)\end{array}$ & $\begin{array}{c}0.000108 \\
(0.000128)\end{array}$ & & & $\begin{array}{c}0.000291^{*} \\
(0.000172)\end{array}$ & $\begin{array}{c}0.000285 \\
(0.000185)\end{array}$ \\
\hline$\Delta$ State UR & & $\begin{array}{l}0.000235 \\
(0.00130)\end{array}$ & & $\begin{array}{l}0.000139 \\
(0.00125)\end{array}$ & & $\begin{array}{l}-0.000930 \\
(0.000996)\end{array}$ & & $\begin{array}{l}-0.00103 \\
(0.00103)\end{array}$ \\
\hline $\begin{array}{l}\text { Share of Pop. with } \\
\text { BD+ / Avg. Age (2000) }\end{array}$ & $\begin{array}{l}0.000445^{* * *} \\
(0.0000374)\end{array}$ & $\begin{array}{c}0.000248 \\
(0.000258)\end{array}$ & $\begin{array}{l}0.00117^{* * *} \\
(0.000120)\end{array}$ & $\begin{array}{c}-0.00240^{* *} \\
(0.00112)\end{array}$ & $\begin{array}{l}-0.00153^{* * *} \\
(0.0000427)\end{array}$ & $\begin{array}{l}-0.000391 \\
(0.000300)\end{array}$ & $\begin{array}{r}-0.00641^{* * *} \\
(0.000102)\end{array}$ & $\begin{array}{c}0.00160 \\
(0.00230)\end{array}$ \\
\hline Occ Fixed Effects & $\mathrm{X}$ & $\mathrm{X}$ & $\mathrm{X}$ & $\mathrm{X}$ & $\mathrm{X}$ & $\mathrm{X}$ & $\mathrm{X}$ & $\mathrm{X}$ \\
\hline State Fixed Effects & $\mathrm{X}$ & & $\mathrm{X}$ & & $\mathrm{X}$ & & $\mathrm{X}$ & \\
\hline Adj. R-squared & 0.0498 & 0.0383 & 0.0500 & 0.0390 & 0.185 & 0.145 & 0.185 & 0.145 \\
\hline Observations & 6641 & 6641 & 6641 & 6641 & 6656 & 6656 & 6656 & 6656 \\
\hline
\end{tabular}

Notes: See data appendix for discussion on the creation of the hourly wage premium by occupation. All specifications include a control for differences between the two time periods, 2007-2010 and 2010-2012. Sample excludes state/occupation observations with fewer than 15 total openings. Observations weighted by the occupation's share of each state's total postings. Standard errors (in parentheses) clustered by state. ${ }^{*} \mathrm{p}<0.10,{ }^{* *} \mathrm{p}<0.05,{ }^{* * *} \mathrm{p}<0.01$ 
Table 9. Relationship between the Change in Employer Requirements and the Business Cycle, with Controls and Initial Hourly Wage Premium

\begin{tabular}{|c|c|c|c|c|}
\hline & \multicolumn{2}{|c|}{$\begin{array}{c}\text { Change in Share of Postings Requesting a } \\
\text { Bachelor's/Graduate Degree }\end{array}$} & \multicolumn{2}{|c|}{$\begin{array}{c}\text { Change in Share of Postings Requesting } \\
>2 \text { Years Experience }\end{array}$} \\
\hline & (1) & $(2)$ & (3) & (4) \\
\hline$\Delta$ State UR & $\begin{array}{l}0.420^{* *} \\
(0.169)\end{array}$ & $\begin{array}{l}-0.109 \\
(0.241)\end{array}$ & $\begin{array}{c}0.773^{* * *} \\
(0.167)\end{array}$ & $\begin{array}{l}0.517^{* *} \\
(0.221)\end{array}$ \\
\hline $\begin{array}{l}\text { Initial Hourly Wage } \\
\text { Premium }(07)\end{array}$ & $\begin{array}{l}3.158^{* *} \\
(1.541)\end{array}$ & $\begin{array}{c}1.567 \\
(1.493)\end{array}$ & $\begin{array}{l}3.330^{* *} \\
(1.507)\end{array}$ & $\begin{array}{l}2.557^{*} \\
(1.450)\end{array}$ \\
\hline $\begin{array}{l}(\Delta \text { State UR)* } \\
\text { (Initial Hr. Wage Prem. (07)) }\end{array}$ & & $\begin{array}{c}1.064^{* * *} \\
(0.366)\end{array}$ & & $\begin{array}{c}0.515 \\
(0.315)\end{array}$ \\
\hline $\begin{array}{l}\text { Initial Share Req. } \\
\text { Skill (07) }\end{array}$ & $\begin{array}{c}-0.347^{* * *} \\
(0.0213)\end{array}$ & $\begin{array}{c}-0.346^{* * *} \\
(0.0211)\end{array}$ & $\begin{array}{c}-0.363^{* * *} \\
(0.0326)\end{array}$ & $\begin{array}{c}-0.363^{* * *} \\
(0.0326)\end{array}$ \\
\hline $\begin{array}{l}\Delta \text { Tot. Postings, } 07-12 \\
\text { / Tot. Emp., } 07\end{array}$ & $\begin{array}{c}-2.032^{* * *} \\
(0.644)\end{array}$ & $\begin{array}{c}-2.032^{* * *} \\
(0.645)\end{array}$ & $\begin{array}{c}-1.829^{* * *} \\
(0.443)\end{array}$ & $\begin{array}{c}-1.827^{* * *} \\
(0.443)\end{array}$ \\
\hline $\begin{array}{l}\text { Share of Pop. with } \\
\text { BD+/ Avg. Age (2000) }\end{array}$ & $\begin{array}{l}0.171^{* * *} \\
(0.0377)\end{array}$ & $\begin{array}{l}0.170^{* * *} \\
(0.0375)\end{array}$ & $\begin{array}{c}0.256 \\
(0.196)\end{array}$ & $\begin{array}{c}0.257 \\
(0.196)\end{array}$ \\
\hline $\begin{array}{l}\text { Occ Fixed Effects } \\
\text { Adj. R-squared } \\
\text { Observations }\end{array}$ & $\begin{array}{c}\mathrm{X} \\
0.312 \\
6685\end{array}$ & $\begin{array}{c}\mathrm{X} \\
0.315 \\
6685\end{array}$ & $\begin{array}{c}\mathrm{X} \\
0.373 \\
6685\end{array}$ & $\begin{array}{c}\mathrm{X} \\
0.374 \\
6685\end{array}$ \\
\hline
\end{tabular}


Table 10. Relationship between the Change in Employer Requirements and the Business Cycle, Veteran Supply Shock

\begin{tabular}{|c|c|c|c|c|c|c|c|c|}
\hline & \multicolumn{4}{|c|}{$\begin{array}{c}\text { Change in Share of Postings Requesting a } \\
\text { Bachelor's/Graduate Degree }\end{array}$} & \multicolumn{4}{|c|}{$\begin{array}{c}\text { Change in Share of Postings Requesting } \\
>2 \text { Years Experience }\end{array}$} \\
\hline & (1) & $(2)$ & (3) & (4) & (5) & $(6)$ & (7) & (8) \\
\hline Log Diff \# Vets & $\begin{array}{c}2.234 \\
(2.061)\end{array}$ & $\begin{array}{c}2.244 \\
(3.203)\end{array}$ & & & $\begin{array}{c}1.349 \\
(1.976)\end{array}$ & $\begin{array}{c}0.487 \\
(2.931)\end{array}$ & & \\
\hline $\begin{array}{l}\text { (Log Diff \# Vets)* } \\
\text { (Vet Share of Occ. Emp.) }\end{array}$ & $\begin{array}{l}0.670^{*} \\
(0.366)\end{array}$ & $\begin{array}{l}0.658^{*} \\
(0.367)\end{array}$ & & & $\begin{array}{l}1.117^{* *} \\
(0.533)\end{array}$ & $\begin{array}{l}1.090^{* *} \\
(0.529)\end{array}$ & & \\
\hline $\begin{array}{l}\text { Vet. BGT Sup/ } \\
\text { Dem Rate }\end{array}$ & & & $\begin{array}{c}1.761^{* * *} \\
(0.504)\end{array}$ & $\begin{array}{l}1.748^{* *} \\
(0.758)\end{array}$ & & & $\begin{array}{c}1.544^{* * *} \\
(0.502)\end{array}$ & $\begin{array}{l}1.455^{* *} \\
(0.674)\end{array}$ \\
\hline Standardized Coefficient & & & 0.109 & 0.934 & & & 0.108 & 0.089 \\
\hline Baseline Controls & $\mathrm{X}$ & $\mathrm{X}$ & $\mathrm{X}$ & $\mathrm{X}$ & $\mathrm{X}$ & $\mathrm{X}$ & $\mathrm{X}$ & $\mathrm{X}$ \\
\hline Occ Fixed Effects & $\mathrm{X}$ & $\mathrm{X}$ & $\mathrm{X}$ & $\mathrm{X}$ & $\mathrm{X}$ & $\mathrm{X}$ & $\mathrm{X}$ & $\mathrm{X}$ \\
\hline State Fixed Effects & & $\mathrm{X}$ & & $\mathrm{X}$ & & $\mathrm{X}$ & & $\mathrm{X}$ \\
\hline Adj. R-squared & 0.314 & 0.335 & 0.321 & 0.340 & 0.365 & 0.394 & 0.369 & 0.397 \\
\hline Observations & 6733 & 6733 & 6733 & 6733 & 6733 & 6733 & 6733 & 6733 \\
\hline
\end{tabular}


Figure 1. Change in the Share of Workers with a College Degree by Occupation

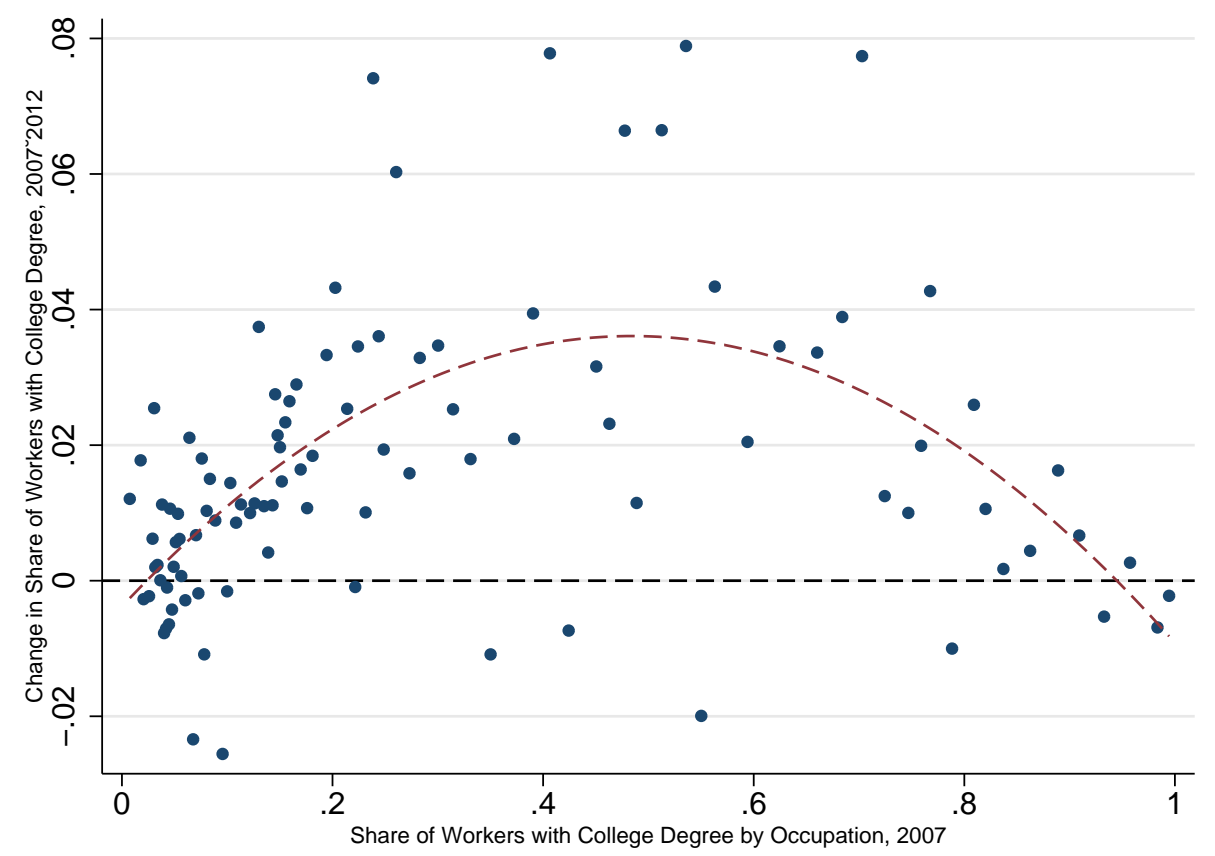

Source: ACS 1yr PUMS, IPUMS-USA, 2007 and 2012. Notes: Red dashed curve represents a quadratic fit line. 
Figure 2. Relationship between Changes in Employer Education and Experience Requirements, 2007-2012

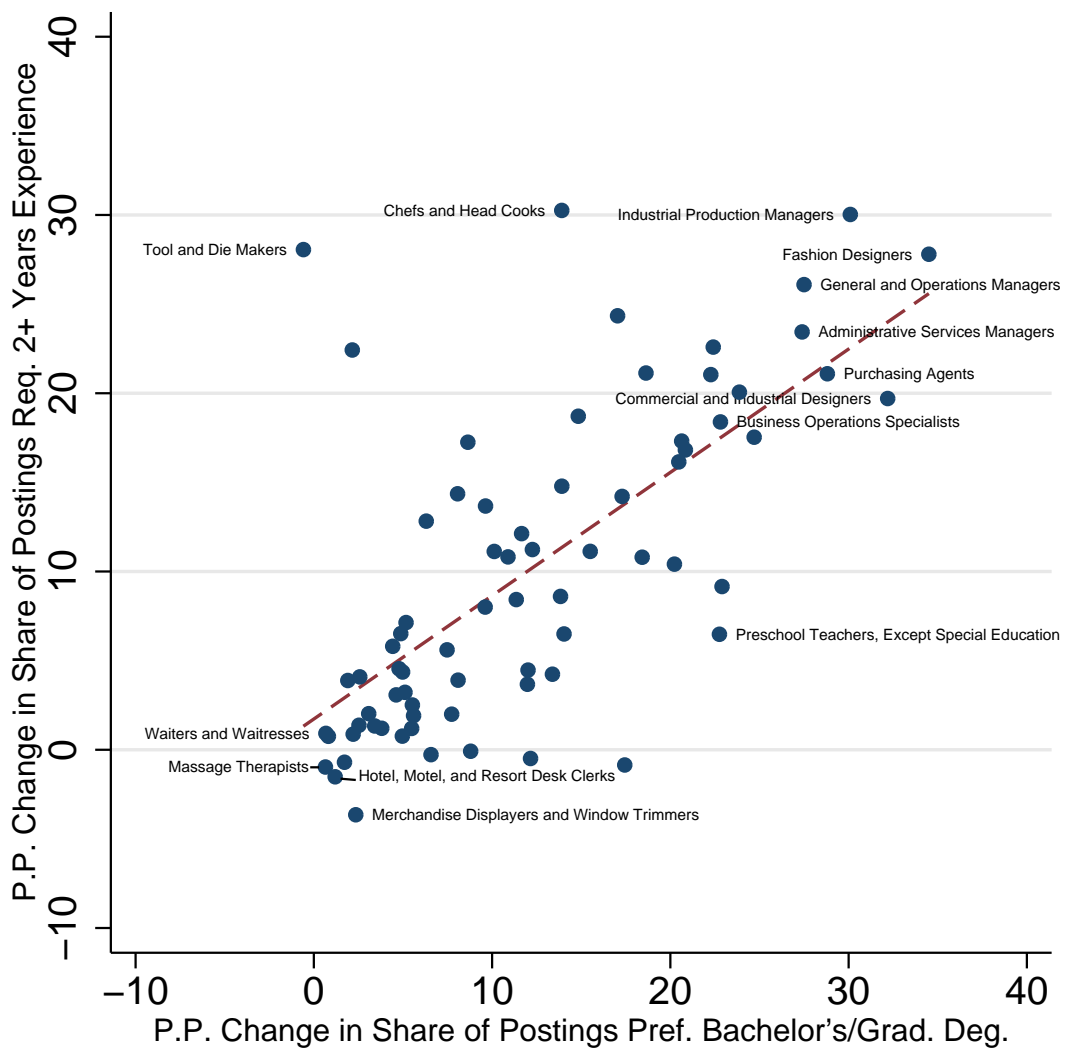

Source: Authors' analysis using data from Burning Glass Technologies, 2007-2012. 
Figure 3. Change in State Unemployment Rate: 2007-2010 versus 2010-2012

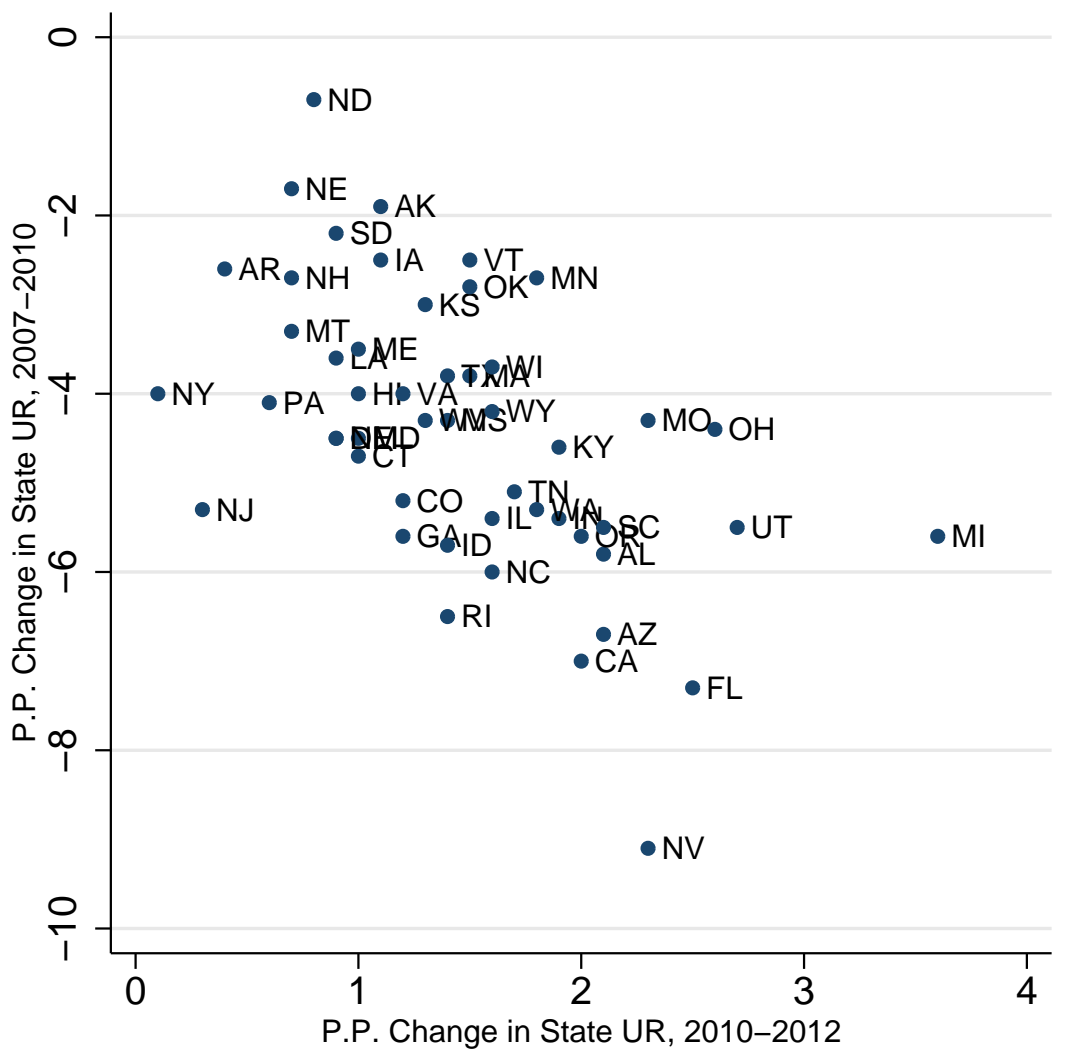

Source: Bureau of Labor Statistics, Local Area Unemployment, 2007-2012. 
Figure 4. Relationship between Changes in Employer Requirements and Labor Supply

Requested Educational Qualifications

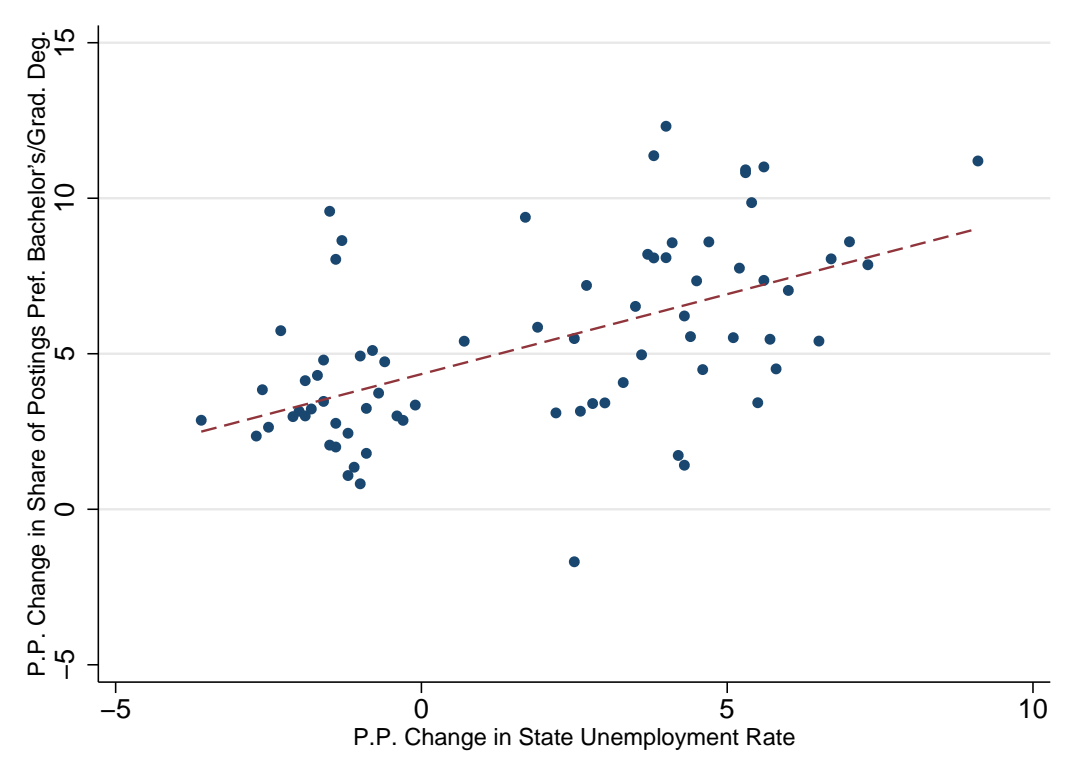

Requested Experience Qualifications

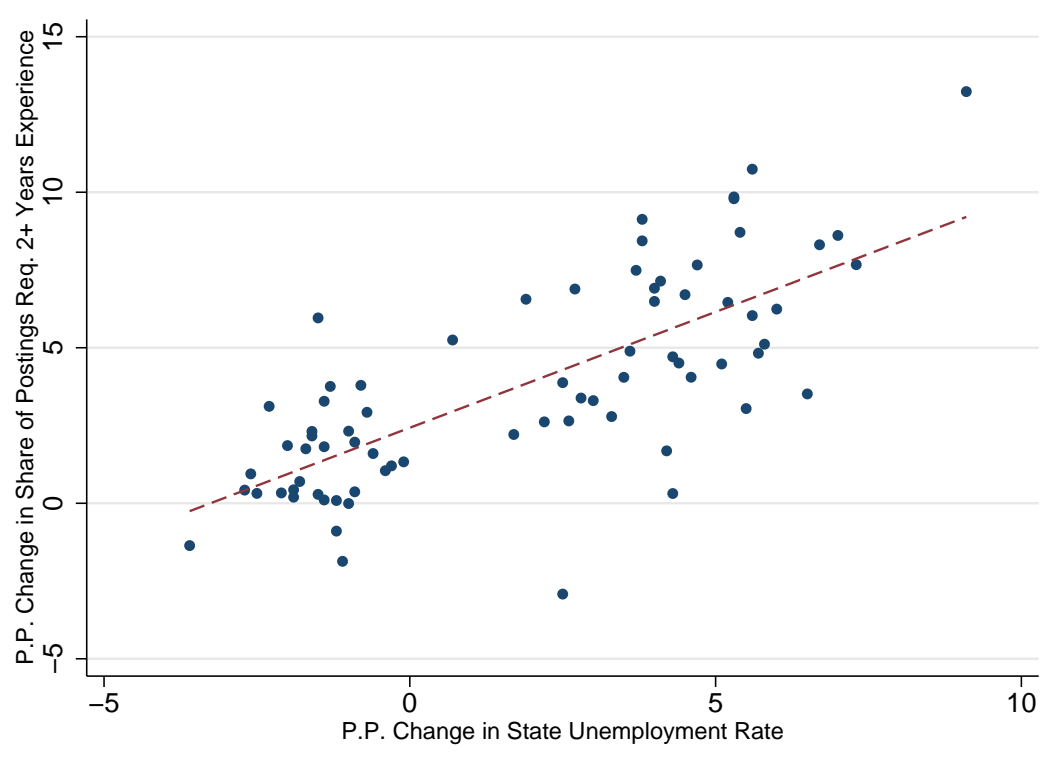

Source: Authors' analysis using data from Burning Glass Technologies, 2007-2012. 
Figure 5. Relationship between Measures of Veteran and Civilian Concentration Across Occupations

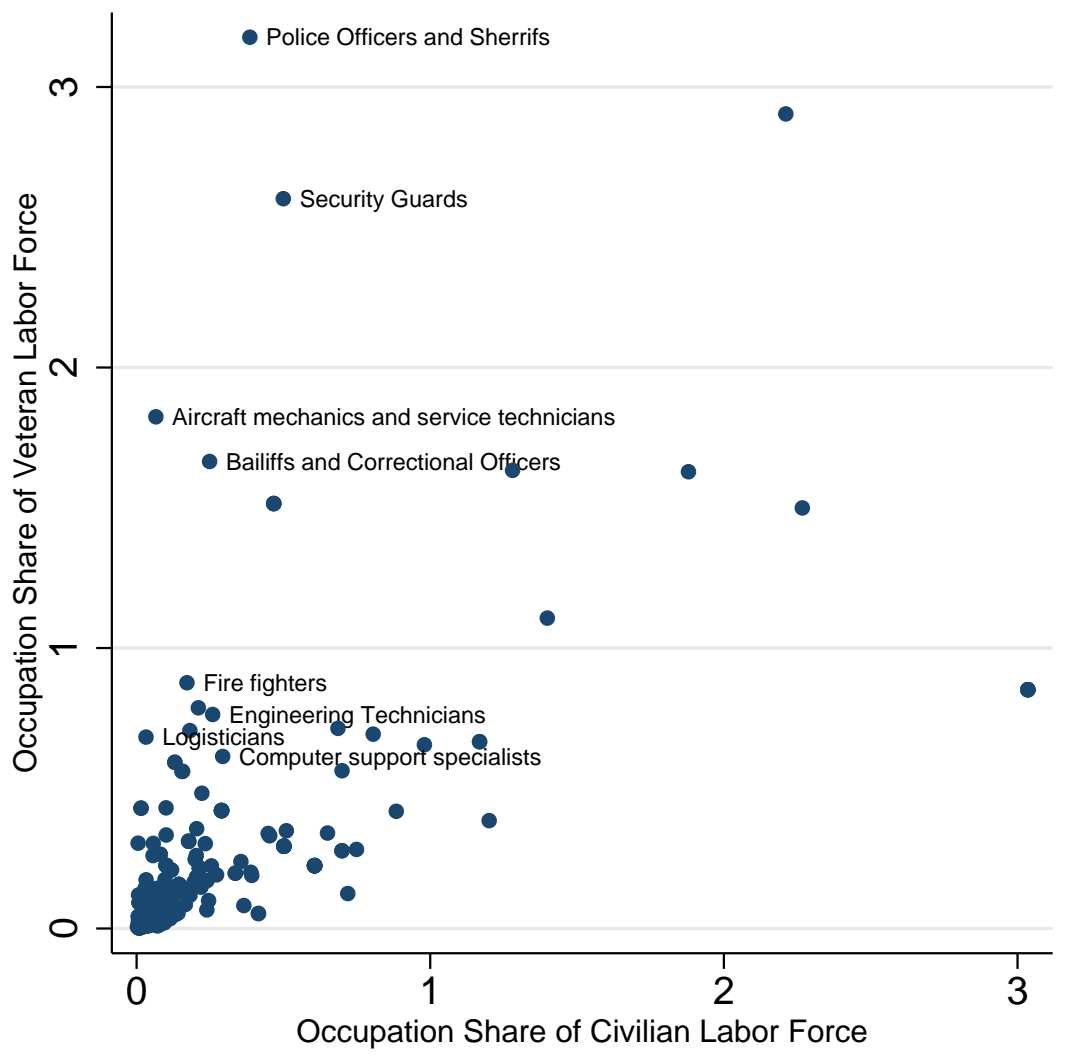

Source: ACS 3yr PUMS, IPUMS-USA, 2005-2007. 
Table A1. Correlation between Alternate Measures of Labor Supply

\begin{tabular}{|c|c|c|c|c|c|}
\hline Level of: & State UR & State UR for BA+ & $\begin{array}{c}\text { State UR for } \\
\text { Workers Aged 35+ }\end{array}$ & $\begin{array}{c}\text { HWOL Broad Occ } \\
\text { Group Sup/Dem } \\
\text { Rate }\end{array}$ & $\begin{array}{c}\text { BGT Broad Occ } \\
\text { Group Sup/Dem } \\
\text { Rate } \\
\end{array}$ \\
\hline State UR & 1.000 & & & & \\
\hline State UR for BA+ & 0.832 & 1.000 & & & \\
\hline State UR for Workers Aged 35+ & 0.964 & 0.856 & 1.000 & & \\
\hline HWOL Broad Occ Group Sup/Dem Rate & 0.747 & 0.629 & 0.676 & 1.000 & \\
\hline BGT Broad Occ Group Sup/Dem Rate & 0.713 & 0.640 & 0.652 & 0.926 & 1.000 \\
\hline Change in: & State UR & $\begin{array}{l}\text { State UR for } \\
\text { BA+ }\end{array}$ & $\begin{array}{c}\text { State UR for } \\
\text { Workers } \\
\text { Aged } 35+\end{array}$ & $\begin{array}{c}\text { HWOL } \\
\text { Broad Occ } \\
\text { Group } \\
\text { Sup/Dem } \\
\text { Rate } \\
\end{array}$ & $\begin{array}{c}\text { BGT Broad } \\
\text { Occ Group } \\
\text { Sup/Dem } \\
\text { Rate }\end{array}$ \\
\hline State UR & 1.000 & & & & \\
\hline State UR for BA+ & 0.911 & 1.000 & & & \\
\hline State UR for Workers Aged 35+ & 0.984 & 0.909 & 1.000 & & \\
\hline HWOL Broad Occ Group Sup/Dem Rate & 0.932 & 0.905 & 0.917 & 1.000 & \\
\hline BGT Broad Occ Group Sup/Dem Rate & 0.900 & 0.892 & 0.874 & 0.956 & 1.000 \\
\hline
\end{tabular}


Table A2. Relationship between Changes in Employer Requirements and the Business Cycle, by Time Period

\begin{tabular}{|c|c|c|c|c|c|c|c|c|}
\hline \multirow{3}{*}{$\frac{\text { Time Period: }}{\Delta \text { State UR }}$} & \multicolumn{4}{|c|}{$\begin{array}{c}\text { Change in Share of Postings Requesting a } \\
\text { Bachelor's/Graduate Degree }\end{array}$} & \multicolumn{4}{|c|}{$\begin{array}{l}\text { Change in Share of Postings Requesting } \\
\qquad 2 \text { Years Experience }\end{array}$} \\
\hline & \multicolumn{2}{|c|}{$2007-2010$} & \multicolumn{2}{|c|}{ 2010-2012 } & \multicolumn{2}{|c|}{$2007-2010$} & \multicolumn{2}{|c|}{ 2010-2012 } \\
\hline & $\begin{array}{c}0.638^{* * *} \\
(0.217)\end{array}$ & $\begin{array}{c}0.674^{* * *} \\
(0.199)\end{array}$ & $\begin{array}{l}-0.198 \\
(0.333)\end{array}$ & $\begin{array}{c}0.104 \\
(0.333)\end{array}$ & $\begin{array}{c}0.893^{* * *} \\
(0.254)\end{array}$ & $\begin{array}{c}0.874^{* * *} \\
(0.192)\end{array}$ & $\begin{array}{c}0.371 \\
(0.343)\end{array}$ & $\begin{array}{c}0.148 \\
(0.357)\end{array}$ \\
\hline $\begin{array}{l}\text { Initial Share Req. } \\
\text { Skill }(07)\end{array}$ & & $\begin{array}{r}-0.629^{* * *} \\
(0.0586)\end{array}$ & & $\begin{array}{l}-0.0614 \\
(0.0600)\end{array}$ & & $\begin{array}{c}-0.562^{* * *} \\
(0.0733)\end{array}$ & & $\begin{array}{r}-0.158^{* * *} \\
(0.0454)\end{array}$ \\
\hline $\begin{array}{l}\Delta \text { Tot. Postings, } 07-12 \\
\text { / Tot. Emp., } 07\end{array}$ & & $\begin{array}{l}-0.957 \\
(0.751)\end{array}$ & & $\begin{array}{c}-3.050^{* * *} \\
(0.867)\end{array}$ & & $\begin{array}{c}-2.102^{* * *} \\
(0.653)\end{array}$ & & $\begin{array}{c}-1.512^{* *} \\
(0.588)\end{array}$ \\
\hline $\begin{array}{l}\text { Share of Pop. with } \\
\text { BD+ / Avg. Age (2000) }\end{array}$ & & $\begin{array}{c}0.514^{* * *} \\
(0.0628)\end{array}$ & & $\begin{array}{c}-0.135^{*} \\
(0.0695)\end{array}$ & & $\begin{array}{c}0.127 \\
(0.459) \\
\end{array}$ & & $\begin{array}{c}0.597 \\
(0.425) \\
\end{array}$ \\
\hline Occ Fixed Effects & & $\mathrm{X}$ & & $\mathrm{X}$ & & $\mathrm{X}$ & & $\mathrm{X}$ \\
\hline Adj. R-squared & 0.0124 & 0.719 & 0.000192 & 0.219 & 0.0227 & 0.702 & 0.00192 & 0.132 \\
\hline Observations & 3409 & 3357 & 3439 & 3376 & 3409 & 3357 & 3439 & 3376 \\
\hline
\end{tabular}

Source: Authors' analysis using data from Burning Glass Technologies, 2007-2012.

Notes: Sample excludes state/occupation observations with fewer than 15 total openings. Observations weighted by the occupation's share of each state's total postings. Standard errors (in parentheses) clustered by state. ${ }^{*} \mathrm{p}<0.10,{ }^{* *} \mathrm{p}<0.05,{ }^{* * *} \mathrm{p}<0.01$ 